\title{
OBSERVATIONS ON THE SPECIES OF DORIPPE FROM THE INDO-MALAYAN REGION
}

\author{
by
}

\author{
R. SERENE and K. ROMIMOHTARTO
}

Among the eight Indo-Pacific species of Dorippe, four inhabiting the Indo-Malayan region were represented in the collection of the National Museum of Singapore. In order to extend our review to all the IndoPacific species, this material was complemented by specimens of three other species, two from Japan, one from Australia. Only one species was not available. The conspicuous differences illustrated by the first male pleopods lead to the partition of Dorippe into five different taxa; two new genera and two new sub-genera are added to Dorippe sensu stricto.

\section{Dorippidae White 1847}

Dorippidea, De Haan, 1841; 120

Dorippidae, White, 1847:53. — Holthuis, 1962:56

Type genus: Dorippe Weber 1795

Dorippe Weber 1795 s.l.

Dorippe, Weber, 1795:33. - Fabricius, 1798:322, 361. - H. Milne Edwards, 1837:154. - De Haan, 1841:121. - Stimpson, 1858:163. 1910:167. - Miers, 1886:327. — Alcock, 1896:275. — Ihle, 1916:148.

Sakai, 1937:71. - 1965:21. — Stephensen, 1945:63. - Barnard, 1950:388. - Holthuis, 1962:55. - Tyndale-Biscoe and George, 1962:66.

Type species: Dorippe frascone (Herbst 1785) described as Cancer frascone Herbst 1785. - Cancer quadridens Fabricius 1793 selected as type species by Latreille $1810=$ Cancer frascone Herbst 1785.

Species of the genus. - Dorippe includes the following Indo-Pacific species: Dorippe frascone (Herbst 1785), facchino (Herbst 1782), granulata De Haan 1841, polita Alcock and Anderson 1894, japonica Von Siebolt 1824, astuta Fabricius 1793, histrio Nobili 1903, australiensis Miers 1884.

The species: quadridens (Fabricius 1798), atropos Lamarck 1818, nodulosa Lamarck 1818, quadridentata H. Milne Edwards 1837 and dorsipes (Authors not Linne) are synonyms of frascone. D. sima $\mathrm{H}$. Milne Edwards 1837 is a synonym of facchino. D. sexdentata Stimpson 1858 was removed into the genus Ethusa by Rathbun (1907) when she published a new edition of Stimpson's works (1858). No material of polita was available for us and our remarks refer only to the authors. 
D. frascone has the widest geographical distribution from the East African Coast to Japan and Australia. D. facchino, polita, astuta and (probably) histrio seem to have a distribution limited to the tropical waters from the Arabian Sea to South China Sea and do not reach East African Coast, Japan, Australia. D. australiensis is endemic of the Australian waters, $D$. japonica and granulata are from off the Japanese and Chinese Seas, including the South China Sea at least for japonica.

The species of Dorippe generally maintain on the back of the carapace a shell or a piece of shell (sometimes it is covered by an actinian) which is hooked by the dactyli and propodi of the pereiopods 4 and 5 . They live on the sandy-muddy and broken-shell bottom of the continental shelf between 10 and $20 \mathrm{~m}$. deep. But two species astuta and polita inhabit the shallow waters of the shores where they live in large communities; Nobili (1903) collected a series of 164 specimens of astuta on one spot and Shen (1932) 235 of polita on one spot.

Separation of the species, — The existing key of Alcock (1896) for the 5 (4) Indian species, of Sakai (1939) for the 3 Japanese species and of Tyndale-Biscoe and George (1962) for the 2 Australian species, are incomplete and by some aspects unsatisfactory.

A special attention must be given to the following morphological characters:

1) The proportion, shape, relief, ornamentation of the carapace: a) ratio of the length of the breadth. - b) convexity or flattening. - c) with tubercles, granules, or smooth. - d) with a covering of strong dense setae, short tomentum or naked.

2) The frontal teeth and extraorbital angles; the infra orbital lobe (tooth).

3) The pereiopods: a) palm of the male cheliped.- b) merus of the pereiopod 3: ratio of its length to the length of the carapace; ratio of its length to its breadth. - c) merus of the pereiopod 4: ratio of its length to the length of the merus of pereiopod 3 , ratio of its length to its breadth. - d) ornamentation of merus, carpus, propodus, dactylus: with or without brushes of dense setae on inferior border; with or without line of long setae on superior border; carpus bicarinate or not.

4) The male abdomen and first pleopod.

Further observations are necessary in order to precise the possible variations of some of those characters in relation to the size and sex of the specimens. The characters of our key are those of adult males which the size is given. All the measurements in the present paper are in millimeters; for the size of the carapace, the first number is the length, the second the breadth. The adult males have a carapace comparatively shorter than the juveniles and sub-adult; the adult females have a carapace comparatively shorter. The ratio of the carapace is that of the largest breadth to the median longitudinal length measured between the vertical line joining the frontal teeth and the 
posterior border of the carapace. The ratio of the breadth measured between the extraorbital angles to the length of the carapace is also significant. The length and breadth of the segments (mainly merus) of the pereiopods 2-3 vary; they seem to be comparatively shorter and wider on the adult male. All our measurements are taken on pereiopod 3 , which is always clearly longer than pereiopod 2 . The brushes of dense setae which exist on the margin of pereiopods 2-3 of some species (like facchino) are less developed and nearly obsolate on the females and the juveniles.

The sexual dimorphism of the male cheliped, marked by one cheliped with the palm strongly swollen seems to exist on all the species of Dorippe. It is much less marked on our specimens of histrio, japonica and australiensis, which probably have not reach their full development.

The shape and ornamentation of the male (and female) abdomen as well as the sternal plates, the shape of the third maxilliped, the disposition of the antennular and antennal peduncle as well as their relations with the frontal margin and orbit, could also assist to precise the specific and subgeneric differentiation.

Alcock (1896) separate polita from the other species by its greater development of the endostomial roof. The condition is nearly identical on australiensis and granulata and seems to have a generic value.

The discrepancies of the morphological characters between the species are sufficient to allow a clear separation of the species into several different groups. By giving the priority to the shape of the male pleopod 1, the grouping suggests that presently the species of Dorippe belong to different genera. Two new genera and four new subgenera are established as follows:

Dorippe (Dorippe) Weber 1795 nov. subgen.

Type species: Dorippe frascone (Herbst 1785)

Dorippe (Dorippoides) nov. subgen.

Type species: Dorippe facchino (Herbst 1782)

Neodorippe (Neodorippe) nov. gen. nov. subgen.

Type species: Dorippe astuta Fabricius 1793

Neodorippe (Nobilum) nov. subgen.

Type species: Dorippe histrio (Nobili 1903)

Paradorippe nov. gen.

Type species: Dorippe granulata (De Haan 1841)

Among the other Indo-Pacific species: japonica is included into $\mathrm{Neo}$ dorippe (Neodorippe); australiensis and polita are included into Paradorippe.

Key of the Separation of the Indo-Pacific species, subgenera and genera of Dorippe s.l.

1 - Male pleopod 1 strong and nearly straight; a rounded lobe on the proximal third of the shaft, which on the subdistal part is densely hairy and not divided into several processes . . . . 2 
- Male pleopod 1 without rounded lobe on the proximal third of the shaft, which is slender or strong, proximally more or less strongly bent and distally deeply divided into several (at least three) chitinuous processes

2 - Male pleopod 1 with the shaft regularly tapering towards the apical chitinuous process.

Dorippe (Dorippe) Weber 1795 s. restr. Dorsal surface of carapace, nodular, wrinkled and entirely hirsute; antero-lateral margin ornamented by strong granules, the largest being the posterior on the branchial region. Carapace nearly as long (0.94) as its largest breadth and 1.40 as long as the extra-orbital breadth. Extraorbital angle much longer than frontal teeth. Infraorbital tooth pounderous, curved and serrated along the under border. Pereiopod 3 with a length 2.8 times the length of carapace; its merus nearly 4 times as long as broad. Merus of the pereiopod 4 is 0.66 times as long as merus of perei opod3.Size:34x32.

\section{frascone (Herbst 1782)}

- Male pleopod 1 with the shaft abruptly narrowing sub-distally to form a neck; the apical chitinuous process distally widening in a ribbon-like process.

Dorsal........................ Dorippe (Dorippoides) nov. subgen. granular (never with tubercle or rub).

Carapace 0.80 as long as its largest breadth, and twice as long as its extraorbital breadth. Frontal teeth short and a few less salient that the acute and distally slender extraorbital angle; inner supra orbital angle acute; infraorbital tooth long, straight, acute and visible in dorsal view. Pereiopod 3 with a length approximately 2.7 times the length of carapace; its carpus slightly bicarinate. Pereiopods 2 and 3 of the adult male with a dense brush of short setae on the two borders (anterior and posterior) of merus and the posterior border of carpus and propodus. Carapace and pereiopods 4-5 covered by a short tomentum. Pereiopod 3 with merus 4.0 times as long as broad. Merus of pereiopod 4 is 0.27 ,as long as merus of pereiopod 3, and 2.66 as long as broad. Size: 24 x 27.

facchino (Herbst 1782)

3(1) - Male pleopod 1 with a slender shaft which is proximally strongly bent and distally divided into at least three subdistal processes or three petaloid lobes. Pereiopods 2-3 slender with merus 5-6 times as long as broad. Pereiopods 2-3 with fringe of long setae on the two margins of carpus, propodus, dactylus. Neodorippe nov. gen. 4

- Male pleopod 1 with a strong swollen shaft constricted at its median length; the distal chitinuous process tricuspid. Roof of 
the endostomial canal projected and dorsally visible between the bases of the frontal teeth.

Paradorippe nov. gen. 6

4(3) - Male pleopod 1 with apex ornamented by a large subacute subdistal process. Neodorippe (Neodorippe) nov. subgen. 5.

- Male pleopod 1 with apex ornamented by three petaloid lobes. ...Neodorippe (Nobilum) nov. subgen.

Carapace nearly as long as broad; its length 2 times its extraorbital breadth. On the carapace several dorsal swellings and tubercles, among them two subconical on the branchial region. Tips of frontal teeth acute and nearly at the same level as the acute tips of extraorbital angle. Infraorbital teeth short but acute. Length of pereiopod 3 is a few more than 3 times the length of carapace with merus a few less than 6 times as long as broad. Pereiopod 4 with merus 0.30 as long as merus of pereiopod 3 . Size:16x17.

histrio (Nobili 1903)

5(4) - Carapace slightly but clearly longer than broad; its length 1.1.3 time its largest breadth and 1.78 times its extraorbital breadth. Carapace flattish and smooth without dorsal tubercles; entirely covered by small tomentum not very dense. Tips of frontal teeth far beyond tips of extraorbital angle. Supra inner orbital angle very feable. Infraorbital teeth small. On the lateral margin of carapace a tubercle marking the end of the branchial sulcus. Length of pereiopod 3 is 3 times the length of carapace, with merus 6 times as long as broad. Pereiopod 4 with merus 0.67 as long as merus of pereiopod 3 and 6.4 times as long as broad. Size:10x9.

astuta (Fabricius 1793).

- Carapace a few shorter than broad, 0.90 as long as its largest breadth; its length 2 times its extraorbital breadth. Tips of frontal teeth subacute and at a level a few beyond the tips of the extra orbital angles. Infraorbital tooth small. Length of pereiopod 3 is 3.6 times the length of carapace; its merus more than 5 times as long as broad, Merus of pereiopod 4 is 0.30 as long as merus of pereiopod 3 and 3.0 times as long as broad. Size: 21 x 21.8. .japonica (Von Siebold 1824).

6(3) - Carapace as long as broad; its length 1.66 times its extraorbital breadth, Carapace flattish and minutely granular and pubescent. Pereiopod absolutely smooth and naked. Frontal teeth very short and with tips nearly at the same level as tips of extraorbital angles, which are acute and relatively long; infraorbital teeth 
well marked but short. Length of pereiopod 3 is 2.4 times the length of carapace with merus 5.6 times as long as broad. Pereiopod 4 with merus 0.46 as long as merus of pereiopod 3. Pereiopods 2-3 with on the superior (posterior) face of the carpus and propodus two longitudinal sulcus; the anterior border of carpus sharply bicarinate Size : $16 \quad x \quad 16$. australiensis (Miers 1884).

- Carapace a few broader than good to be kept.

7 - Carapace granular and slightly tomentose. Carapace 0.92 as long as its largest breadth and 2.10 as long as its extraorbital breadth. Extraorbital angle at the same level as frontal teeth. On perei opods 2-3 only some short setae on anterior border of propodus. Pereiopod 3 with merus nearly 4 times as long as broad. Merus of pereiopod 4 is 0.41 as long as merus of pereiopod 3 and 3.7 as long as broad. Size: 18.7 x 20.8. granulata (De Haan 1841)

- Carapace flattened, finely granular and tomentose. Carapace 0.95 as long as its largest breadth and 1.77 as long as its extraorbital breadth. Extraorbital angle slightly behind the level of frontal teeth. Infraorbital tooth short and curved. Pereiopods 2-3 devoided of any setae. Pereiopod 3 with merus 4.42 times as long as broad; merus of pereiopod 4 is 0.45 as long as merus of pereiopod 3 and 4.6 as long as broad. Size: $11.8 \times 12.6$. polita (Alcock and Anderson 1894).

Dorippe (Dorippe) Weber 1795 nov. comb.

Definition. - Carapace wrinkled with dorsal tubercles; antero-lateral border granular with the posterior larger, granule like an epibranchial tubercle. Male pleopod 1 with shaft strong and nearly straight, regularly tapering distally toward the chitinuous process.

Typo species: Dorippe (Dorippe) frascone (Herbst 1785).

The presence of an epibranchial tubercle could suggest that the two atlantic species: Dorippe lanata (Linne 1767) and D. armata Miers 1881 could also be included in the subgenus. The first male pleopod of lanata (ses Barnard 1959, fig. 73d) has the same type.

\section{Dorippe (Dorippe) frascone (Herbst 1785)}

figs. 1, 5, 10, 15A, B. - P1. IA, B; IIIA, B, C.

Cancer frascone, Herbst, 1785:192.

Dorippe frascone, Holthuis, 1962:54. - Tyndale-Biscoe and George, 1962:66.

Dorippe atropos, Lamarck, 1818:245.

Dorippe nodulosa, Lamarck, 1818:245. — Bosc, 1801:208. pi. 4, fig. 2. Guerin, 1829-1844, pi. 13, fig. 2. 
Cancer quadridens, Fabricius, 1793:464.

Dorippe quadridens, Fabricius, 1798:361. — Bosc, 1801:207. — Latreille, 1810:422, pi. 306, fig. 1. — Desmarest, 1826:135. — De Haan, 1841:121, pi. 31, fig. 3. - Stimpson, 1858:163. — De Man, 1888:398. — Estampador, 1937:515.

Dorippe quadridentata, H. Milne Edwards, 1837:156. — Berthold, 1846: 20. - Hilgendorf, 1878:812. — Nauck, 1880:49. — Haswell, 1882:137.

Dorippe dorsipes, Miers, 1884:185 and 257. — De Man, 1887:393. — Cano, 1889:254. — Ortmann, 1892:562. - Henderson, 1893:404. — Alcoek, 1896:277. — Lanchester, 1900:769. - 1901:553. - Rathbun, 1902:31. - 1910:305. - 1911:199. - 1923:138. — Nobili, 1902:172. - 1903:24. — Borradaile, 1903:24. — Laurie, 1906:267. — Stimpson, 1907:167. — Parisi, 1919:300. — Ihle, 1916:148. — Balss, 1922:119. — Gravely, 1927:, pi. 25, fig. 41. — Andre, 1931:639. — Shen, 1931:138. - 1932:98, pi. 5, figs. 1-2, text-figs. 5-7. - 1940a :213. - 1940b :76. — Sakai, 1934:283. - 1936:40, pi. 6, fig. 3. - 1937:73, pi. 10, fig. 4. - 1965:21, pi. 10, fig. 4. Gravely, 1941: (not seen). - Stephensen, 1945:63, fig. 4A, B. - Bar nard, 1950:390, fig. 73. - Pillai, 1951:13. — Utinomi, 1960:69, pi. 35, fig. 1.

Not Cancer dorsipes. Linne, 1758 = Notopus dorsipes (Linne 1758).

Material - NMS.1965.10.11.29, male of 33 x 33, NMS.1965.10.11.30, male of 34 x 34, NMS.1965.10.11.30, male of 36 x 36, Loc. Siglap, Singapore, Coll. Tweedie 7/1934, Det. Tweedie as D. dorsipes.

Remarks on Nomenclature and Type specimens. - Miers (1884), who is the first to use with reserve the name dorsipes Linne for quadridens Fabricius, writes: "If this species be not truely $D$. dorsipes of Linnaeus, it would appear (as Hilgendorf notes) that Herbst's name of D. frascone has still priority over the Fabrician designation."

In a paper devoted to the designation of a type species for Dromia, Holthuis (1962) states that the name dorsipes Linne 1758 cannot be maintained for a Dorippe and must be replaced by frascone (Herbst 1785).

The specimens figured by Herbst is the holotype of the species; however, in case Herbst's material consisted of more than one specimen, we select the figured specimen as the lectotype. The type specimens of Herbst was maintained in the Berlin Museum but does not exist any more, as at our request we have been informed by Dr. Gruner (personnal letter), Curator of Crustacea of this Museum. Dr. Holthuis kindly assisted us for this selection of the holotype.

Observations. - Our specimens are from a large series of the National Museum of Singapore. Among 8 males specimens with nearly the same size, 4 have the chelipeds strongly unequal, 4 nearly subequal, as illustrated by our photographs. Without being absolute, it seems that only male with a size of carapace over 34 has one of their cheliped with swollen palm. The first male pleopod is more accurately illustrated by Barnard (1950, fig. 73c) than by Stephensen (1945, fig. 4A). The species is well characterized by: 1) the dense covering of setae on the carapace and pereiopods, save on the propodus and dactylus of 
pereiopods 2-3. - 2) the relief of the carapace with conspicuous tubercles. - 3) the granules ornamenting the chelipeds, save the palm on adult male. -4) the infra-orbital tooth serrate. - 5) the male pleopod 1 tapering regularly toward the distal chitinuous process.

The shape and ornamentation of the male and female abdomen as well as the sternal plates, with lines of granules and some large tubercles are conspicuous and in some extend could have subgeneric value. The species is the most frequently recorded with the widest Indo-Pacific distribution, but does not reach Hawaii.

\section{Dorippe (Dorippoides) nov. subgen.}

Definition, - Carapace without wrinkled or tubercles, smooth or finely granular. Male pleopod with strong and nearly straight shaft abrubtly narrowing (like a neck) before the apex which has a long and ribbon-like crescent shaped chitinuous process.

Type species: Dorippe (Dorippoides) facchino (Herbst 1782).

\section{Dorippe (Dorippoides) facchino (Herbst 1782) \\ figs. 2, 6, 11, 16A, B.C.D. - PI. IC; HID.}

Cancer facchino, Herbst, 1782:190, pi. 11, fig. 68.

Dorippe facchino, De Haan, 1841:123. - Stimpson, 1858:163. — Miers, 1886:328. - Henderson, 1893:405. - Ortmann, 1892:561. — Alcock, 1896:278. — Laurie, 1906:367. — Rathbun, 1910:305. — Ihle, 1916:156. - Andre, 1931:640. - Shen, 1931:100, text-fig. 8, pi. 5, fig. 3, 4. 1940a :213. - 1940b :75. - Stephensen, 1945:64, fig. 4C.

Dorippe granulata Alcock, 1896:279 (not granulata De Haan 1841).

Dorippe facchino var. alcocki, Nobili, 1903:25.

Dorippe sp., De Man, 1888:206.

Dorippe sima, H. Milne Edwards, 1837:157, pi. 20, fig. 2. - Dana, 1852:398.

Miers, 1880:317. - Walker, 1886:111.

Material. — NMS.1969.9.21.1, male of 21 x 24, Loc. Pahang, Malaysia, R. Serene coll. 8/1965 and det.; NMS.1969.2.24.2, male of 17 X 20, Loc. Thailand, R. Serene coll. 11/1965 and del; NMS.1969.2.24.3, male of 21 x 17, Loc. Siglap, Singapore, Tweedie coll. 12/1933; NMS.1969.2.24. 4, female of 21 x 26, Loc. Siglap, Singapore, Tweedie coll. 12/1933; IM. 520, Colombo Museum, male of 24 x 27.

Remarks on Nomenclature and Type specimens. - Andre (1931) indicates that the name facchino is mentioned for the first time for Cancer hirsutus personatus by Plancus (1739:36, pi. 6, fig. 1.), a crab which has some resemblance with a human face, and called (facchino ${ }^{r}$ by the resident of Rimini (Italia) and is a Dorippe.

Andre (1931) states that: 1) Herbst (1782) includes under Cancer facchino two species one from Europe: C. lanatus Linne 1767 and one from Asia: C. facchino. - 2) H. Milne Edwards (1837) considers that the figure of Herbst (1782, pi. 11, fig. 68) for facchino corresponds to the male of 
lanata illustrated by Herbst (1782, pi. 11, fig. 67). - 3) facchino is restricted to the Asian form with reference to De Haan (1841). He suggests that the name of $D$. sima $\mathrm{H}$. Milne Edwards 1837 should be used instead of that of Herbst 1782.

Dr Holthuis (in a personal letter) states: "Cancer facchino Herbst is a composite species. Herbst described and figured the Asiatic species and in his synonyms referred to the Mediterranean material of Plancus. So far as I know, no one has ever been selected a lectotype for the species .. Restricting activities like those of De Haan, H. Milne Edwards, Andre, etc ........ are not valid as they do not indicate a lectotype."

The type material consisting of the specimen (or specimens) of the Herbst' collection (one of which is illustrated pi. 11, fig. 68) and Plancus' collection (p. 36, pi. 5, fig. 1) does not exists anymore. Following a suggestion of Dr Holthuis, we select as lectotype the specimen figured by Herbst (pi. 11, fig. 68) in order to save the name facchino for the Indo-West Pacific species.

History and discussion. - De Haan (1841) does not record any specimen from Japan; he examines without giving any reference to its locality of origin a specimen (D. facchino Herbst I; 190, pi. 11, fig. 68) from "Collectione Daldorfiana" which was communicated to him and compared by him with $D$. japonica and $D$. granulata. Stimpson $(1858,1910)$ records as facchino specimens from Hongkong. Miers (1886) records a male of 23.5 x 27.5 from Hongkong; Henderson (1893) specimens from Madras; Ortmann (1892) one male and one female from the Indian Ocean; Alcock (1896) from Madras and the East Coast of India; the largest male of $29 \mathrm{X}$ 34; Rathbun (1910) from the Guilf of Thailand; Andre (1931) from Vietnam; Shen (1931, 1940a) from Hongkong, the largest male of 22.6 x 27.3 and (1940b) from several localities of China: Shaotsun, Foochow, Tsimei; Stephensen (1945) from the Iranian Gulf.

De Haan (1841) mentions that he sees no difference between sima and facchino. Stimpson (1858), followed bv Miers C1886) makes sima $\mathrm{H}$. Milne Edwards 1837 a synonym of facchino. H. Milne Edwards (1837) describes sima for specimens from the Indian Sea. Dana (1851) only mentions specimens from Singapore. Miers (1880) records one female from Borneo; Walker (1886) records specimens from Singapore. In the brief original description of $\mathrm{H}$. Milne Edwards (1837) at least one character seems to contradict the definition of facchino. $\mathrm{H}$. Milne Edwards writes: "dent du bo,rd inferieur de Porbite mediocre, arrondie, lisse et ne depassant pas le niveau du front." But on the illustration of $\mathrm{H}$. Milne Edwards (1837. pl. 20, fig. 12) the infra orbital tooth is long, acute and exactly that of facchino. Mme Guinot (in a personal letter) informed us that it was not possible to find in the National Museum of Paris the type specimen of $\mathrm{H}$. Milne Edwards which must be considered as lost. However Miers (1884:259) in describing $D$. australiensis with a small inner orbital angle, writes: "in $D$. sima .... there is a strong spine at the inner suborbital angle."

Alcock (1896) refers with a doubt to granulata a series of specimens, which he suggests further to be perhaps a variety of facchino. They 
are all small (the largest being an ovigerous female of $14 \times 16$ ) and differ from facchino by: 1) the carapace a little more granular. - 2) the pereiopods 2-3 without brushes of setae on the margin. - 3) the chelipeds of male hardly asymmetrical. Nobili (1903) records 12 males and females from Singapore (without giving any size of the specimen) which he considers as identical to the specimens identified as granulata by Alcock (1896) and gives the name of facchino var. alcocki to this form. The senior author has the opportunity to examine some of the specimens of Alcock (1896) in the Indian Museum and thinks that they are only juvenile of facchino.

Observations. - Our specimens of facchino agree with the description of Alcock (1896) and Shen (1931) as well as to the illustrations of Shen (1931) and Stephensen (1945). With reference to those authors the main characters of the species are: 1) a carapace much broader than long, smooth and entirely covered by a short tomentum (some fine granule on antero lateral sides). - 2) the pereiopods 2-3 of male with brushes of setae on anterior border of merus and posterior border of merus, carpus, propodus. - 3) the tips of the extraorbital angle broad and suddenly accuminate projects to the level of the frontal teeth. - 4) the infra-orbital tooth slender, straight, acute (visible in dorsal view) projects well beyond the frontal teeth. - 5) the adult male cheliped strongly unequal with palm of the largest swollen. - 6) on pereiopods 2-3, carpus slightly bicarinate. - 7) first male pleopod with stout basal part rather abruptly cut off, not apically tapering; the horny distal process rather long and ribbon-like.

We have examined a large series of specimens of the collection of the National Museum of Singapore; only the male larger than 21 as length of the carapace have the cheliped strongly unequal with the largest strongly swollen. On the specimens smaller than 18 as length of the carapace, the brushes of setae on the pereiopods 2-3 are always less developed and generally only exist on the posterior border of the merus. An observation which confirms our views to consider var alcocki as a juvenile of facchino.

The following measurements made on 4 males specimens illustrate the variations of the characters of the pereiopod 3, used in our key.

\begin{tabular}{lcccc} 
& 1 & 2 & 3 & 4 \\
\hline Carapace length Lc & 20 & 17 & 13.5 & 13 \\
Carapace breadth Bc & 25 & 20 & 16 & 15 \\
ratio Lc/Bc & 0.80 & 0.85 & 0.84 & 0.86 \\
Merus of pereiopod 3 & & & & \\
Length Lp3 & 20.5 & 19 & 16.5 & 14 \\
Breadth Bp3 & 5 & 4.5 & 4 & 3 \\
ratio Lp3/Bp3 & 4.10 & 4.22 & 4.12 & 4.66 \\
ratio Lp3/Lc & 1.02 & 1.11 & 1.22 & 1.07
\end{tabular}

The species is known from the Gulf of Iran to Hongkong as northern limit; it is not recorded from South Africa, Japan, Australia. It is found 
on the sandy or muddy bottom at $15-100 \mathrm{~m}$. Henderson (1893) writes that it is "protected by the valve of some lamellibranch, e.g. Placuna to which an Actinia is attached." Alcock (1896) indicates as covering "bivalve shell and sea anemone". Shen (1931) mentions "every single specimen possessed a living coelenterate thus attached....... probably Velella lata Chamisso and Eysenhardt or closely allied to it". Velella being a Siphonophoria and the Coelenterata living on Dorippe an Actinian, the identification of Shen (1931) seems to be a mistake. On our specimens, we always found a small valve of lamellibranch in the middle of the ventral face of the sole of the Actinian. The shell is much smaller than the dorsum of the carapace of the Dorippe, the sole of the Actinian on the contrary is much larger and laterally extends over the carapace covering partly the pereiopods $2-3$. Probably the young crab hooks a small valve of lamellibranch on which the Actinian begins to develop. The Actinian becomes larger and larger at the same time that the carapace of the crab increases (but comparatively much less) in size. The crabs can always let slip away the Actinian, but we think that the association of the two organisms is the same individual one for the life time.

Neodorippe (Neodorippe) nov. subgen.

Definition. - Carapace flattish or slightly convex, with dorsal surface smooth or wrinkled and tuberculate. The pereiopods 2-3 very slender; the length of the pereiopod 3 at least three times as long as the length of the carapace and its merus 6 times as long as broad. The male pleopod with a slender shaft proximally strongly bent; distally it is divided into three subapical or apical process.

Type species: Dorippe astuta Fabricius 1793. The subgenus Neodorippe (Neodorippe) is restricted to the species with the apex of the male pleopod 1 similar to that of astuta. It includes japonica and a new var taiwanensis.

The shape of the male abdominal segment 3 with two large symmetric rounded swellings (related ? to the type of pleopod) seems to have some value as generic character. In the genus the proximal part of the shaft of the first male pleopod is strongly bent backward and then forward. In natural conditions this U-shaped proximal part is fitted into a large cavity of the abdominal segment 3 , which is the first in ventral position; the segment abdominal 1 and 2 being dorsal. The pleopod 1 of the three species of the genus belong to the same type but the apex of histrio is so different from those of astuta and japonica that it is separated under a new subgenus Nobilum.

Neodorippe (Neodorippe) astuta Fabricius 1793

figs. 3, 7, 12, 17A, B. - PL ID; PI. IVA, B.

Cancer astutus, Herbst, 1795:4, pl. IV, fig. 6.

Dorippe astuta, Fabricius, 1793:361. - Bosc,' 1801:02: 208. - H. Milne Edwards, 1837:157. — Walker, 1886:111. — Ortmann, 1892:562. 
- Henderson, 1893:405. - Alcock, 1896:280. — De Man, 1896:370. Nobili, 1899:496. - 1903a: 12. - 1903b :26. — Rathbun, 1910:305. — Shen, 1940b :76. - Chhapgar, 1957:409 (11), pl. 3, fig. d, e. Not Dorippe astuta Haswell, 1882:136 = australiensis.

Material — NMS. 1969.2.24.5, female of 16 x 15;' NMS. 1969.2.24.6, male of 11 x 10, Loc. Siglap, Singapore, coll. and det. Tweedie 12/1933.

History. - We have no information on the type specimen. H. Milne Edwards (1837) records the species from the Asian seas. Walker (1886) records specimens from Singapore; Henderson (1893) records one male of 12 x 11 and one female of 13 x 40 from Madras and mentions that the species is recorded by White from the Philippines and Indian Ocean. De Man (1896) record specimens from Celebes; Alcock (1896) several specimens from the Andamans and Mergui Islands, Orissa coast (India) and Karachi (Pakistan), the largest male of 12 x 11.5. Ortmann (1892) records 2 females from Singapore; Nobili (1899) records one female from Nias; Nobili (1903a) one female of 14 x 14 from Singapore and (1903b) 164 specimens from Sarawak. Rathbun (1910) one male, one female, one juvenile from Gulf of Thailand (Koh Chik, Koh Chang). Shen (1940b) records 8 males and 2 females from several localities (Amoy, Tsimei, Santuao) of South China. Chhapgar (1957) records a male of 11.5 x 10.75 from Bombay.

Observations. - The only illustrations available are those of Herbst (1795) and Chhapgar (1957) ; the best description is given by Alcock (1896). Chhapgar (1957) describes correctly the male pleopod 1 with "a tip like a tin-opener, with one crecentric tip, and the other bent over itself." As a larger magnification the structure appears to be a few more complicated.

Our specimens are selected from several large series of specimens of the National Museum of Singapore. The males are smaller; the largest does not exceed 12 as length of the carapace; our largest female has 16.

In Singapore the species is very common on the mangrove swamps and generally all specimens hook a leaf of a mangrove tree on their backs. Alcock (1896) mentions on his specimens that: "one carries across its back a large (inhabited) worm tube, which is said by Dr Gilles to be a habit with this species." Rathbun (1910) mentions one specimen "crept about with a large "leaf over it." The crab uses the leaf to conceal under as a protection. Shen (1932) on polita, a species also living on shores and shallow waters writes: "Found in tide pools on sandy beach. This crab always protects itself by holding a bivalve shell upon its dorsal surface with its two prehensile posterior legs. When it was frightened, it soon stopped to move in water and concealed itself quietly under the shell or suddenly threw it off and fled away when any danger approaches to it." Obviously the use of a leaf by astuta is also temporary and the relation between* one individual crab and its protection is different in nature of what we have suggested to be between facchino and an Actinian. 
Neodorippe (Neodorippe) japonica Von Siebold 1824

figs. 19, 20A, B. - PI. IIA; VC; VIA.

Dorippe japonica, Von Siebold, 1824:14 (not seen).

Dorippe callida, De Haan, 1841; pl. 31, fig. 1. - Not seen.

callida, Fabricius.

Dorippe japonica, De Haan, 1841:122. - Stimpson, 1858:163.Parisi, 1914:302. — Balss, 1922:119. - Shen, 1931:101, pl. 6, fig. 1-2. 1932:111, fig 6-7a-e. - 1940a :213. - 1940b :75. — Sakai, 1937:72, pl. 10, fig. 1.

Material. - Institute of Oceanography of Nhatrang, E.3380'2, male of 18 x 20, Loc. Nhatrang Bay, Vietnam, from Trawlers of fishermen, sandy muddy bottom, $12 \mathrm{~m}$. deep, R. Serene coll. and det. 10/1956.

NMS.1969.5.5.1-2, male of 19 x 21; female of 21 x 24; Loc. Nagasaki, Japan. Sakai coll. and det.

History. - The Type material from Japan is probably maintained in the Leyden Museum; to our knowledges no lectotype have been selected. The species is recorded from Japan by all the authors, except Shen (1931, 1940a) who records it from Hongkong. The present extends the distribution of the species in the South China Sea.

Observations, - The present males have probably not reach their full development and the chelipeds are still feable and subequal; the largest specimen quoted in the literature is a male of 21 x 21.8 (Sakai 1937). The species is close to histrio but differs clearly at least by the relief of its dorsal surface and its male pleopod 1 , which is very close to that of astuta.

On our specimens the merus of the pereiopod 3 is much longer than the lenght of the carapace like on the figure of Sakai (1937, pi. 10, fig. 1). On the figure of Shen (1932, fig. 6) the merus of pereiopod 3 is nearly equal to the length of the carapace. The figure represents a female; the legs are always comparatively a few shorter on the female than on the male, but still the specific difference is strongly marked. According to his figure the specimen of japonica has the pereiopod 3 less than 3 times the length of carapace instead of a few more than 3 times on japonica, and a merus 4.5 times as broad as long instead of more than 5 times on our specimen and Sakai's figure (1937).

In the text, Siren (1932) quotes a male with a carapace of 19 as length and pereiopod 3 with 58 as length, a female with a carapace of 22 as length and pereiopod 3 with 63 as length; the ratio of the length of pereiopod 3 to the length of carapace is 3.27 for the male, 2.86 for the female. On our specimen the ratio is more than 3.6. Sakai (1937) gives 3.4 for the pereiopod 2, which is much shorter; Shen, (1932) for the pereiopod 2 gives 51 as length, which gives a ratio 2.83 for the length of the pereiopod to the length of the carapace. The position of the specimens of Shen (1932) in regard to japonica is doubtful and the variations of the species need further observations. The use of the total length 
of the pereiopods request a more precise definition; it seem better to use the total length of the merus, carpus, propodus, dactylus without including ischium and coxa, like below we do for the taiwanensis nov. var.

Neodorippe (Neodorippe) japonica var. taiwanensis nov. var. figs. 21, 22. - PI. VA, B, D.

Material. - NMS. 1969.2.24.7-8, holotype, male of 15.5 x 16; paratype, female of 17 x 17. - Loc. Keelung, Taiwan, coll. Fisheries Research Institute, 1963; Serene det. 10/9/1968.

Observations. - The new variety differs from japonica (our male specimen of japonica of $19 \times 21$ taken as reference material) by: 1) A smaller size; our male of taiwanensis has already the swollen palm of one of the. cheliped, which characterizes the adult; our japonica (19 x 21) has the two chelipeds sub-similar and elongate. - 2) The longer and slimmer ambulatory legs; on taiwanensis the merus of the pereiopod 3 has 19 as length and is clearly longer than the largest breadth of the carapace; on our japonica, the pereiopod 3 has 21 as length and is subequal to the largest breadth of the carapace. The total length of the pereiopod 3 (ischium and coxa excluded) is 3.2 times the length of the carapace on taiwanensis, and 3.0 on japonica. The merus is 5.93 times longer than broad on taiwanensis, 5.25 on japonica. - 3) The apex of the pleopod 1 with the subdistal and distal process is slightly different.

In regard to the character 1 , it must be mentioned that among the available illustrations of male of japonica those of Shen (1931, pi. 6, fig. 2), Sakai (1937, pi. 10, fig. 1), Ward (1937) does not have a swollen cheliped. We have expressed our doubts about the identity with japonica of the specimens of Shen (1932, fig. 6-7) ; He gives a size of 17 x 19.5 for one male and his figure (7c) show a swollen palm which he indicates as "abnormal development". In his text he mentions that on japonica the chelipeds of male are "sometimes asymmetrical." In any way by the characters of its slimmer and longer pereiopods 2 and 3, taiwanensis clearly differs from the form studied by Shen (1932).

Several other less clear characters separate taiwanensis from japonica. On taiwanensis the infra orbital tooth is comparatively less acute and more granular; the relief on the sternal shield a few more marked. The observation of much more material of the forms japonica and aff. is necessary to precise the variations of the species. It would confirm or infirm the value of our variety, as well as precise the position of the form studied by Shen (1932). The specimens of taiwanensis were sorted out by the senior author from a container where the Fisheries Research Institute of Keelung kept miscellaneous specimens collected by trawlers and their precise locality is unknown.

Neodorippe (Nobilum) nov. subgen.

The subgenus is characterized by the apex of the pleopod 1 with three petaleous lobes. The Type species of the subgenus is Dorippe histrio Nobili 1903. 
Dorippe histrio, Nobili, 1903:24 (with a photograph on a plate without reference). — Rathbun, 1929:99. - Shen, 1940b :76.

Material - NMS.1965.10.11.50, male of 21 x 22, Loc. Penang, Coll. Fisheries Depart, in a fishing trap, 6/1934, identified as Dorippe sp. in the NMS. collection;

History. - Nobili (1903) describes the species for 3 males of $20 \times 20$, 16.5 x 16, 16.5 x 16 and 2 females of 21 x 22, 22.5 x 23 from Singapore. The type material is probably maintained in the Torino Museum. We select the largest male of Nobili as lectotype. Rathbun (1929) records the species from Foochow and Yenting (China) in a list, indicating only that the specimens are in the U.S. National Museum collection. Shen (1940) quotes the species in a list with reference to the record of Rathbun (1929).

Observations. - Nobili (1903) situates the species as close to dorsipes (= frascone) and astuta giving accurate characters to separate it from those two species. By the relief of the carapace the species is closer to frascone than to any others. But at least by the shape of its male pleopod and its slender long pereiopods 2-3 it is more closely related to astuta.

\section{Paradorippe nov. gen.}

Definition. - Carapace flattish more or less granular with sparely minute pubescence; all pereiopods, entirely naked. The length of pereiopod 3 is nearly two and a half as long as the carapace; its merus five and a half as long as broad. The first pleopod has a strong swollen shaft, divided in the middle by a constriction, looking like an articulation; the junction of the two halves making an obtuse angle. The superior half is distally ornamented by 3 subdistal and distal chitinuous processes.

Type species: Dorippe granulata De Haan 1841.

\section{Paradorippe granulata (De Haan 1841)}

$$
\text { figs. 23, 24, 25, 29. - P1 IIC; VIC. }
$$

Dorippe granulata, De Haan, 1841:122, pl. 31, fig. 2. - Stimpson, 1858:163. - 1907:167. - Targioni Tozetti, 1877:19, pl. 12, fig. 5. — Ortmann, 1892:561. — Rathbun, 1902:31. — Parisi, 1914:301. — Balss, 1922: 119. Yokoya, 1933:107. - Shen, 1931:102, pl. 6, fig. 3, 4. - 1932:15, text-figs. 8-9, pl. 1, fig. 12. - 1940a :214. - 1937:74, pl. 10, fig. 5. - 1965:22, pl. 11, fig. 1.

Material. - NMS.1969.5.5.3, male of 23 x 26. - Mikawa Bay, Japan. Sakai coll. and det.

History. - The species is described for specimens from Japan. The Type material is probably maintained in the Leyden Museum; to our knowledge no lectotype have been selected. The species is accurately described and illustrated by Shen (1931, 1932) and Sakai (1936, 1937, 1965). Its geographical distribution is limited to Japan and China with 
Hongkong (Stimpson, Shen) as southern limited and Vladivostok as northern limit. It is found on sandy or muddy bottom at 50-130 m. deep. It generally hooks on its back a valve of death lamellibranch or other material such as a piece of dead Laganum (Sakai 1937).

Observations. - The male pleopod 1 very strong and constricted in the middle on its shaft, is distally ornamented by 4-5 chitinuous processes. The longer is the median distal and is tricuspid; at its base there are two shorter and foliaceous ones; less distally two other processes are one elongated like a finger, the other like a lobe.

Paradorippe australiensis (Miers 1884) figs.

9, 14, 26, 27, 28A, B. - P1, IID; P1. VIB, D.

Dorippe australiensis, Miers, 1884:258, pl. 26, fig. D. - Grant and Mac Culloch, 1906:26. — Rathbun, 1924:27. - Tyndale-Biscoe and George, 1962:66, figs. 2, 3.

Dorippe astuta, Haswell, 1882:136, not astuta Fabricius.

Material. - W.A.M. (Western Australian Museum) No. 329-60, Loc. Cockburn Sound, Australia, St. 19 W.A. Naturalists' Club, 28/5/1958, Dredged, one male of $14.0 \times 14$ and another male of $16.2 \times 16$, det. by Tyndale-Biscoe and George, 1962.

History. - Miers (1884) describes australiensis for a specimen (Holotype) of Port Denison (Australia), two specimens from Moreton Bay and four others from Australian coasts; all are maintained in the British Museum. Grant and Mac Culloch (1906) mention a good series of specimens from the Australian Museum dredged from Port Curtis (Australia) and correct the specimens identified as astuta by Haswell (1881) as australiensis. Rathbun (1924) records from off Cap Jaubert (by 70 feet) one female of $11.8 \times 12$ and one small male; the last carrying on its back a valve of Antigona (Venus) lagueata Sowerby. Tyndale-Biscoe and George (1962) record a series of specimens from several localities of Western Australia.

Observations. - Our specimens are two of the series of the Western Australian Museum recorded by Tyndale-Biscoe and George (1962) and kindly lent to us by Dr George. These authors give an accurate illustration and definition of the first male pleopod. From their description we quote: "short, square and bent. Tip pointed, carrying three unequal teeth; terminal tooth longest with three small hooks." At a larger magnification those "three small hooks" correspond to a trilobate process with one lobe longer and the two others widely united together. The subdistal teeth correspond one to a long foliaceous and accuminate process, and the other (second tooth) to a series of four digitations less acuminate and an accessory lobe near their base. For a quick examination, the drawing of Tyndale-Biscoe and George (1962, fig. 2. 3) are perhaps more useful, giving a better illustration of the anchor-like aspect of the apex under low magnification. The species is endemic from the Australian waters; it would be interesting to look at its possible extension to the Arafura Sea. 
Paradorippe ? polita (Alcock and Anderson 1894).

Dorippe polita, Alcock and Anderson, 1894:208. - 111. Invest., 1896, pl. 24, fig. 4. - Alcock, 1896:281. — Shen, 1932:8, text-figs. 4, 5, pl. 1, fig. 11. - 1940b :76.

History. - Alcock and Anderson (1894) describes polita. for 2 females, the largest of $11.5 \times 12$ from the Madras Coast collected at 7 fathoms deep. Alcock (1896) mentions the same material. Shen (1932) records 242 males and 170 females from several localities of China. He collected the species in the tide pools on sandy beach, holding a bivalve shell on its back. He mentions a male of 11.8 x 12.6 as largest specimen, Shen (1940b) records 3 males and 3 females from several localities of China: Foochow, Tsimei, Amoy. The species being recorded from the coast of India and China and from the intertidal zone probably also occurs in the IndoMalayan region. Alcock and Anderson (1894) consider that polita is "nearest to D. sexdentata Stimpson" and "in many aspects resembles Ethusa more closely than Dorippe"; but is "a true Dorippe." Since sexdentata was moved into Ethusa. The species is relatively close to astuta as mentioned by Alcock (1896), has a similar habitat in shallow waters and could perhaps belong to the same subgenus Neodorippe. But it is also close to granulata and australiensis by several characters, like the greater development of the roof of the endostomial canal. The examination of its male pleopod 1 is necessary to decide of its correct position.

Remark on the male intromittent organs of Dorippe s.1.

The particular shape of the male pleopod 1 leads to give some attention to the male external sexual apparatus of the Dorippidae (s. restr. Gordon 1963) = "Dorippidae sternistremen" as a whole. The different types of male pleopod 1 in this taxon have been used by us for the separation of new genera and subgenera; but still more detailed observations on this appendix are needed, A brief remark is given here on the condition of the pleopod 2 and penis of Paradorippe granulata in order to call attention on the need of further observations.

The terminal segment of the pleopod 2 in natural condition is distally invaginated into the pleopod 1; the limit of its intromission is indicated by a dotted line on our figure. It has the habitual shape found on many Brachyura. The subdistal article is strongly elongated and as long as the terminal; the two are rounded and brown and ornamented by some setae on their borders. The proximal is made of a slim white plate and has its surface covered with large and long setae.

The origin of the penis on dorsal view is clearly visible on the coxa of the pereiopod 5. After passing below the sternite 8, like under a bridge, it runs free along the sternal suture ,7/8 and distally reaches the base of the pleopods 1 and 2 .

In the Dorippidae s. restr. (sternitremen), the female genital opening are sternal. On the "peditremen" Brachyura, like Dromiacea, Gymnopleura and Tymolinae, where the female genital opening are coxal, the 
penis is free. The penis of Tymolus japonious and Cymonomus granulatus have been illustrated by Gordon (1963, fig. 11). On the Gymnopleura (manuscript in press of the senior author) the penis is situated at the tip of an elongated process formed by the border of the coxa of the pereiopod 5.

\section{Addendum made at proofs correcting.}

Since the present work was given to the printer, SANKAEANKUTTY (1968, fig. 15, 16) illustrates the male pleopod of D. granulata and D. polita for specimens from India. Like all specimens of granulata recorded from India, the specimen of SANKARANKUTTY (1968) according to his drawing of the male pleopod is a facchino. The drawing of the pleopod of polita confirms that the species belongs to Paradorippe.

\section{REFERENCES}

Those marked with an * have not been seen by the authors.

Alcock, A.W., 1896. Materials for a carcinological fauna of India, No. 2. The Brachyura Oxystomata. J. Asiat. Soc. Bengal, 65(1) :134-296, pls. 6-8.

Alcock, A.W. and Anderson, A.R.S., 1894. National History notes from the "Investigator" Serie 2, No. 17. List of the shore and shallow water brachyura collected during the season 1893-1894. J. Asiat. Soc. Bengal, 63(2) : 197-209.

Andre, M., 1931. Crustaces decapodes provenant de I'Institut Oceanographique de Nhatrang. Bull. Hist. Nat. Paris, (2), 3:638-650.

Balss, H., 1922. Ostasiatische Decapoden, III, Die Dromiaceen, Oxystomen und Parthenopiden. Archiv. für Naturges, 88, (3) A: 104-140, figs. 1-9.

Barnard, K.H., 1950. Descriptive catalogue of South African Decapod Crustacea. Ann. South Afr. Mus. 38: 1-837, figs. 1-154.

Chhapgar, B.F., 1957. On the marine crabs (Decapoda: Brachyura) of Bombay state, Part I. J. Bombay Nat. Hist. Soc, 54: 399-439, 2 pls., 1 fig. - Contr. 1 of the Taraporevala Mar. Biol. Stat., Bombay, p. 1-89, 16 pls.

Dana, J.D., 1852. Crustacea. United States Exploring Expedition during the years 1838, 1839, 1840, 1841, 1842, 13 (1): I-VIII and 1-685.

Estampador, E.P., 1937. A check list of Philippines Crustacean Decapoda. Philippines Journ. Sci., 62: 465-559.

* Fabricius, J.C., 1798. Supplementatum Entomologiae Systematicae, Huaniae: 1-572.

Grant, F.E. and MacCulloch, A.R., 1906. On a collection of Crustacea from the Port Curtis District, Queensland. Proc. Linn. Soc. N.S Wales, 31 (1): 1-53, pls. 1-4.

Gravely, F.H., 1927. Orders Decapoda (except Paguridea) and Stomatopoda. The littoral fauna of Krusadai Island in the Gulf of Manaar. Bull. Madras Gov. Mus. 1, (1): 135-155, fig. 1-2, pls. 19-26.

Haswell, W.A., 1882. Catalogue of Australian Stalk and Sessile-eyed Crustacea. The Australian Museum Sydney: 1-326, 4 pls.

Henderson, J.B., 1893. Contribution to Indian Carcinology. Trans. Linn. Soc. London Zool. (2) 5: 325-458, pls. 36-40.

*Herbst, J.F.W., 1782-1804. "Versuch einer Naturgeschichte der Krabben und Krebse." I-III (Berlin). 
Holthuis, L.B., 1962. Dromia Weber, 1795 (Crustacea Decapoda): Proposed designation of a type species under the plenary powers. Z.N.(S.) 1488. Bull. Zool.t Nom. 19(1): 51-57.

Ihle, J.E.W., 1916. Die Decapoda Brachyura der Siboga-Expedition. - II, Oxystomata, Dorrippid. Siboga-Expeditie, 39, b2: 97-158, figs. 1-39.

Lanchester, W.F., 1900. On a collection of Crustaceans made at Singapore and Malacca. (1), Crustacea Brachyura. Proc. Zool. Soc. London (1): 719-770, pls. 44-47.

Laurie, D., 1906. Report on the Brachyura, collected by Prof. Herdman at Ceylon in 1902. Report to Colonial Government on the Pearl Oyster Fisheries of the Gulf of Manaar, 5 (5) : 349-432, pls, 1-2.

Man, J.D. de, 1888. Report on the Podophthalmus Crustacea of the Mergui Archipelago collected for the Truste of Indian Museum, Calcutta, by Dr. J. Anderson, superintendant of the Museum. Part I-IV. Journ. Linn. Soc. London, 22: 1312, pls. 1-19.

Miers, E.J., 1880. On a collection of Crustacea from the Malayan Region. II - Telphusidae, Catometopa and Oxystomata. Ann. Mag. Nat. Hist. 4: (5), 304-384. , id. Part III: 457-472, pls. 1-3.

1884. Crustacean. Report on the Zoological collections made in the Indo Pacific Ocean during the voyage of H.M.S. "Alert" 1881-82: 178-322, 513575, pls. 18-34, 46-52. British Mus. Nat. Hist. London.

1886. Report on the Brachyura collected by H.M.S. "Challenger" during the years 1873-1876. Report Scient. Res. Voyage H.M.S. "Challenger", Zool. . Part 49, 17, (III) : 1-362, 29 pls.

Milne Edwards, H., 1834. Histoire naturelle des Crustaces. 1-3: 1-461, 1-531, 1-638, pls. 1-342.

Nobili, G., 1900. Contribuzioni alia conoscenza della fauna arcinologica della Papuasia, delle Molucche e dell' Australia. Ann. Mus. Civ. Stor. Nat. Genova, (2) 20:473-523.

-, 1903a. Contributione alla fauna carcinologica di Borneo. Bol. Mus. Zool. Anat. Comp. R. Univ. Torino, 18,-No. 447: 1-32, 3 figs.

-,1903b. Crostacei di Singapore. Bool. Mus. Zool. Anat. Comp. R. Univ. Torino, 18, No. 455: 1-39, 1 pl.

Ortmann, A.E., 1892. Die Decapoden-Krebse des Strassburger Museums. V - Hippidea, Dromiidae und Oxystomata. Zool. Jahr. Iena. Abt. fur Syst., 6: 532-588, pl. 26.

Parisi, B., 1914. Decapodi giapponesi del Musee di Milano I. Oxystomata. Atti. Soc. Ital. Sc. Nat. Milano, 53: 5-35, 5 text-figs., pls. 11-13.

Pillai, N.K., 1951. Decapoda (Brachyura) from Travancore. Bull. Centre Res. Inst. Univ. Travancore, 2 C (I): 1-46, 5 figs.

Rathbun, M.J., 1910. The Danish Expedition to Siam 1899-1900. V. Brachyura. Mem. Acad. Roy. Sc. Danem. Cop., 7e Sar., 5, (4) : 303-368, figs. 1-44, pls. 1-2. , 1911. The Percy Sladen Trust. Expedition to the Indian Ocean in 1905, 3, (II) Marine Brachyura. Trans. Linn. Soc. London (2), 14, (2) : 191-261, pls. 15-20.

1923. Reports on the Crabs obtained by F.I.S. Endeavour 1909-1914 in the coast of Queensland. (Biological Result "Endeavour", Vol. 4) Reports on Fisheries. Bull. Fish. Dep. Com. Australia, 5, (3) : 93-156, pls. 16-42. 1929. New and Rare Chinese Crabs. Lignan Science Journal (Contr. Lign. Agric. Rev.) 8: 75-104, pls. 3-15.

Sakai, T., 1934. Brachyura from the coast of Kyusyu. (Contr. from Simoda Marine Biological Station). Sc. Rep. Tokyo Bunrika Daigaku, B, 1, No. 25: 281-330. , 1936. Crabs of Japan. 66 Plates in Life colours with descriptions, Tokyo (Japanese). 
Sakai, T., 1938. Studies on the Crabs of Japan. II. Oxystomata, Sc. Rep. Tokyo Bunr. Daig. B, 3, Supp. No. 2: 67-192, 45 text-figs., pls. 10-19. , 1965. The Crabs of Sagami Bay collected by H.M. the Emperor of Japan. Maruzen, Tokyo, p. I-XVI, 1-206 (English part), text-figs. 1-27, colour plates $1-100$.

Shen, C.J., 1931a. The Crabs of Hongkong. Part I. Hongkong naturalist, 2(2): 92110,pls.1-10,11text-figs. 1931b. The Crabs of Hongkong. Part II. Hongkong naturalist, 2(3): 185-197, pls. 12-14, 13 text-figs.

, 1932. The Brachyuran Crustacea of North China, Zoologica Sinica, Ser. A. 9, (1): 1-320, pls. 1-10, text-figs. 1-171.

Shen, C.J., 1940a. The Brachyura fauna of Hongkong. Journ. Hongkong Fish. Res. Stat,1,No.2:24-242.

1940b. On the collections of Crans of South China. Bull. Fan. Mem. Inst. Biol Zool. ser. 10: 69-104.

Stephensen, K., 1946. The Brachyuran of the Iranian Gulf, with an appendix: The male pleopod of the Brachyura. Danish Sclent. Invest. Iran, Copenhagen; 57-237, figs. 1-60.

Stimpson, W., 1858a. Prodromus descriptionis animalium evertebratorum quae in Expeditione ad Oceanum Pacificum Septentrionalem, a Republica Federata missa, Cadwaladaro Ringgold et Johanne Rodgers Ducibus, observavit et descripsit. Part VI - Crustacea Oxystomata. Proc. Acad. Nat. Sc. Philadelphia,10:158-163(57-61).

1907. Report on the Crustacea (Brachyura-Anomura) collected by the North Pacific Expedition 1853-56. Smith. Misc. coll. Washington, 49: 1-240, pl. $1-26$.

Targioni Tozetti, A., 1877. Zoologia del Viaggio Intorno al Globo della R. Piro corvetta Magenta durante gli anni 1865-68. Crostacei Brachiuri e Anomuri. Publ. R. Inst. Stud. Sup. Firenze, Sez. Sc. Nat. I: I-XXIX, 1-257, pl. I-XIII.

Tyndale-Biscoe, M. and George, R.W., 1962. The Oxystomata and Gymnopleura (Crustacea, Brachyura) of Western Australia with description of two new species from Western Australia and one from India. J. Roy. Soc. W. Aust.,45: 65-96, 3 pls., 9 figs.

Walker, A.D., 1887. Notes on a collection of Crustacea from Singapore. Journ. Linn. Soc. London, Zool. ser. 20: 107-117, pls. 6-9.

Weber, F., 1795. "Nomenclator Entomologicus Secundum Entomologiam Systematicum III. Fabricii Adjectis Speciebus Recens Detectis et Varietabilis."

Yokoya, Y., 1933. On the distribution of Decapod Crustaceans inhabiting the Continental Shelf around Japan, chiefly based upon the Material, collected by S.S. Soyo Maru, during the years 1923-1930. Journ. Coll., Agric. Tokyo Imp. Univ., 12, No. 1: 1-226, 71 text-figs. 


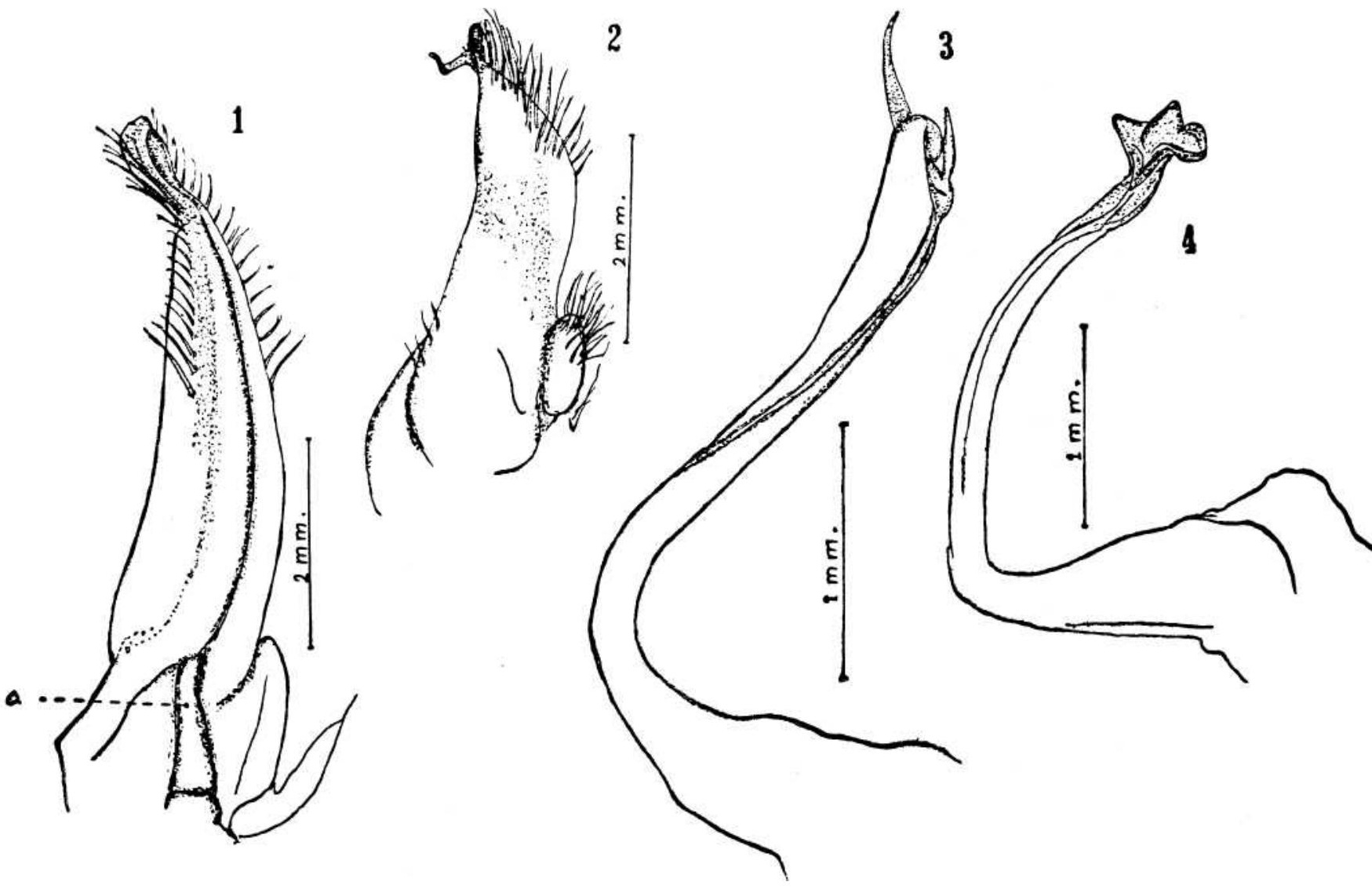

Figures 1-4

First male pleopod: 1, Dorippe (Dorippe) frascone, male of 33 X 33. - 2, Dorippe (Dorippoides) facchino, male of 21 X 24. - 3, Neodorippe (Neodorippe) astuta, male of 11 X 10. - 4, Neodorippe (Nobilum) histrio, male of 21 $\mathrm{X} 22$. 

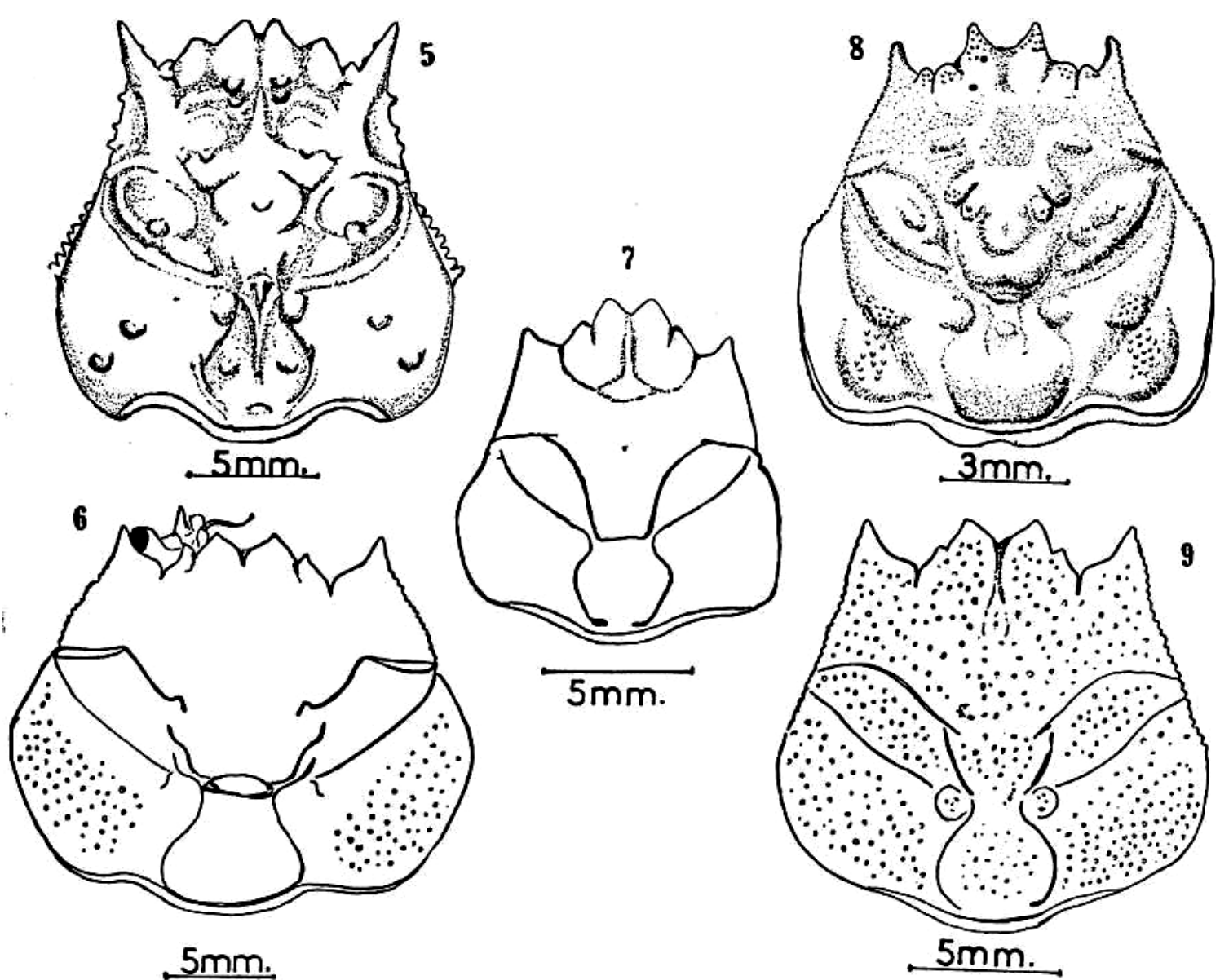

Figures 5-9.

Carapace of: $5, D$. (Dorippe) frascone. - 6, D. (Dorippoides) facchino. - 7, $N$. (Neodorippe) astuta. - 8, N. (Nobilum) histrio. - 9, Paradorippe australiensis. 

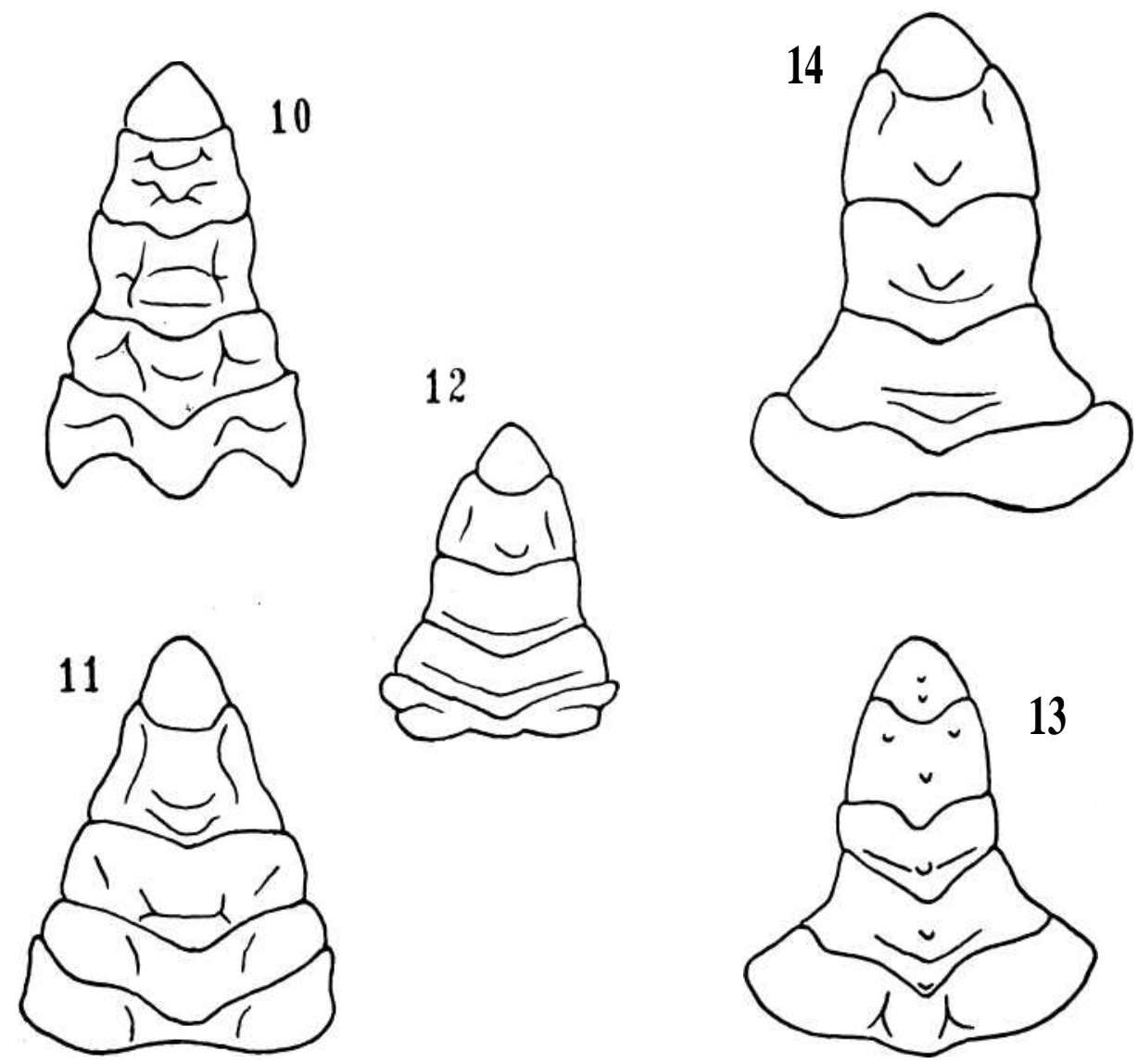

Figures 10-14.

Male abdomen of: $10, D$. (Dorippe) frascone. - 11, D. (Dorippoides) facchino. - 12, N. (Neodorippe) astuta. - 13, N. (Nobilum) histrio. - 14, Paradorippe australiensis 

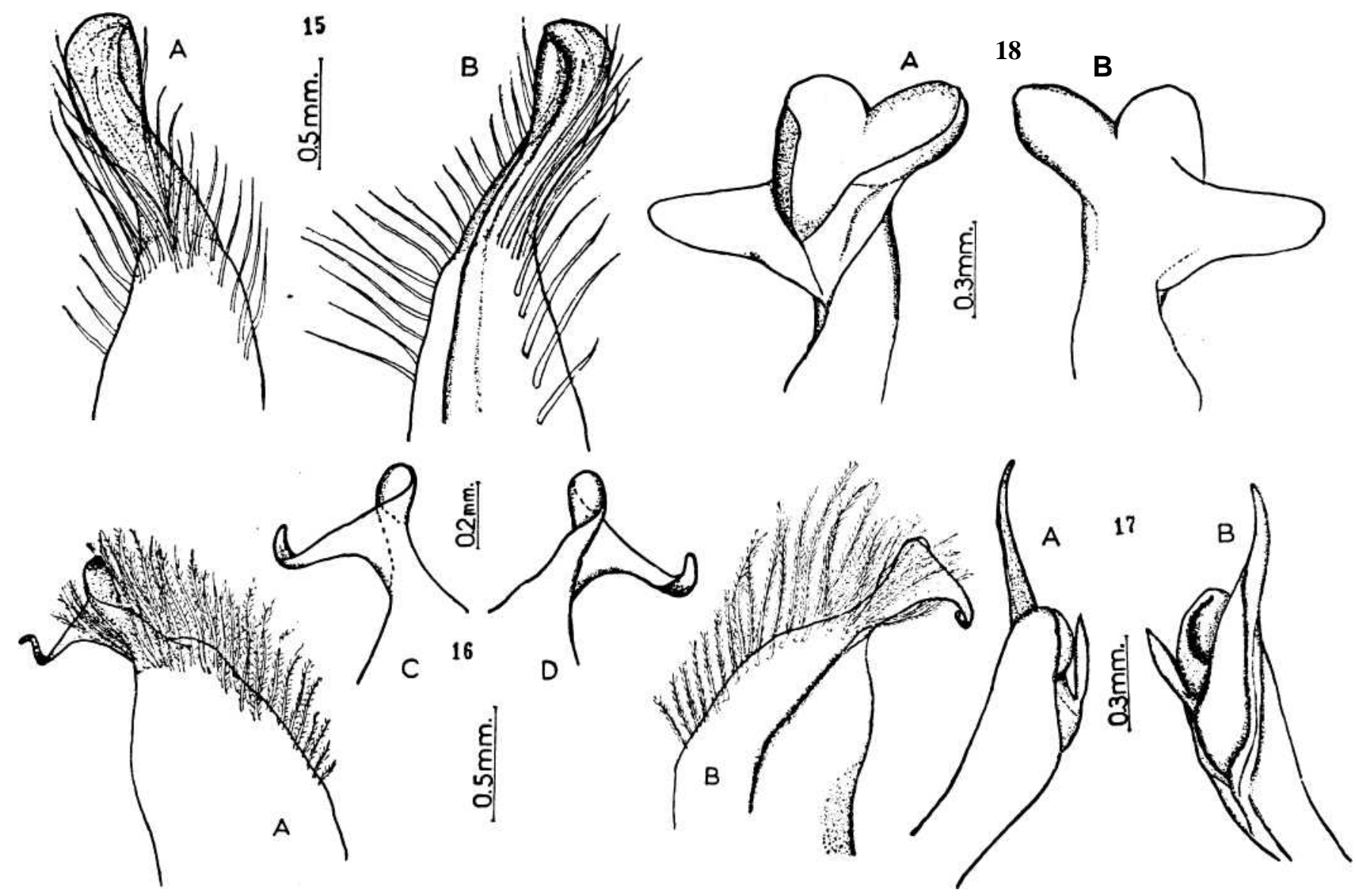

Figures 15-18.

Apex of first pleopod male of: 15A, B, D. (Dorippe) frascone, male of 32 X 24. - 16A, B, C, D, D. (Dorippoides) facchino, male of 21 X 24. - 17A, B, N. (Neodorippe) astuta, male of 11 X 10. - 18A, B, N. (Nobilum) histrio, male of $21 \mathrm{X} 22$. During printing, the fig. 16B was by accident reversed. 

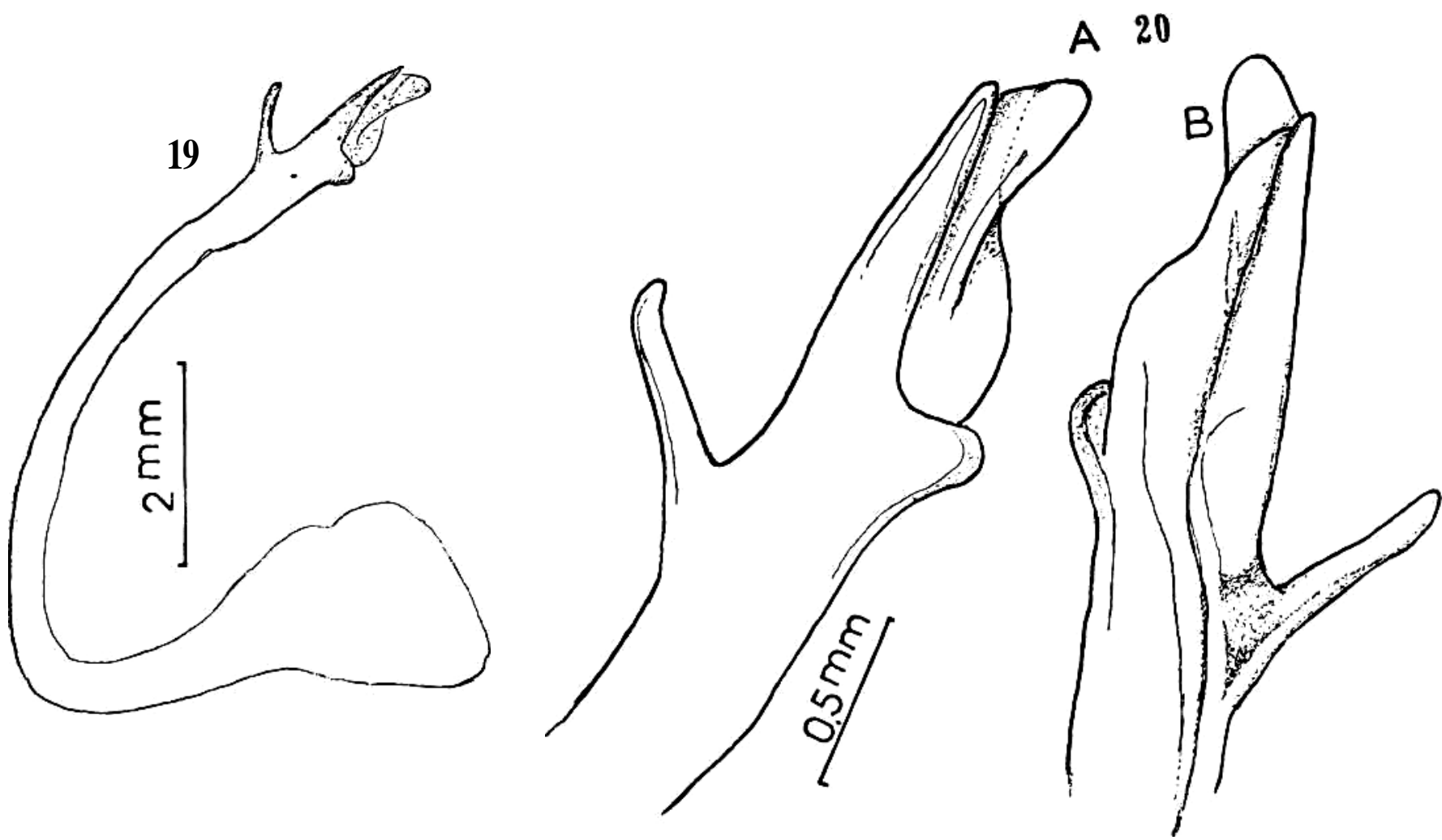

Figures 19-20.

First pleopod of $N$. (Neodorippe) japonica, male of 18 X 20: 19, entire pleopod. 20A, B, distal part. 


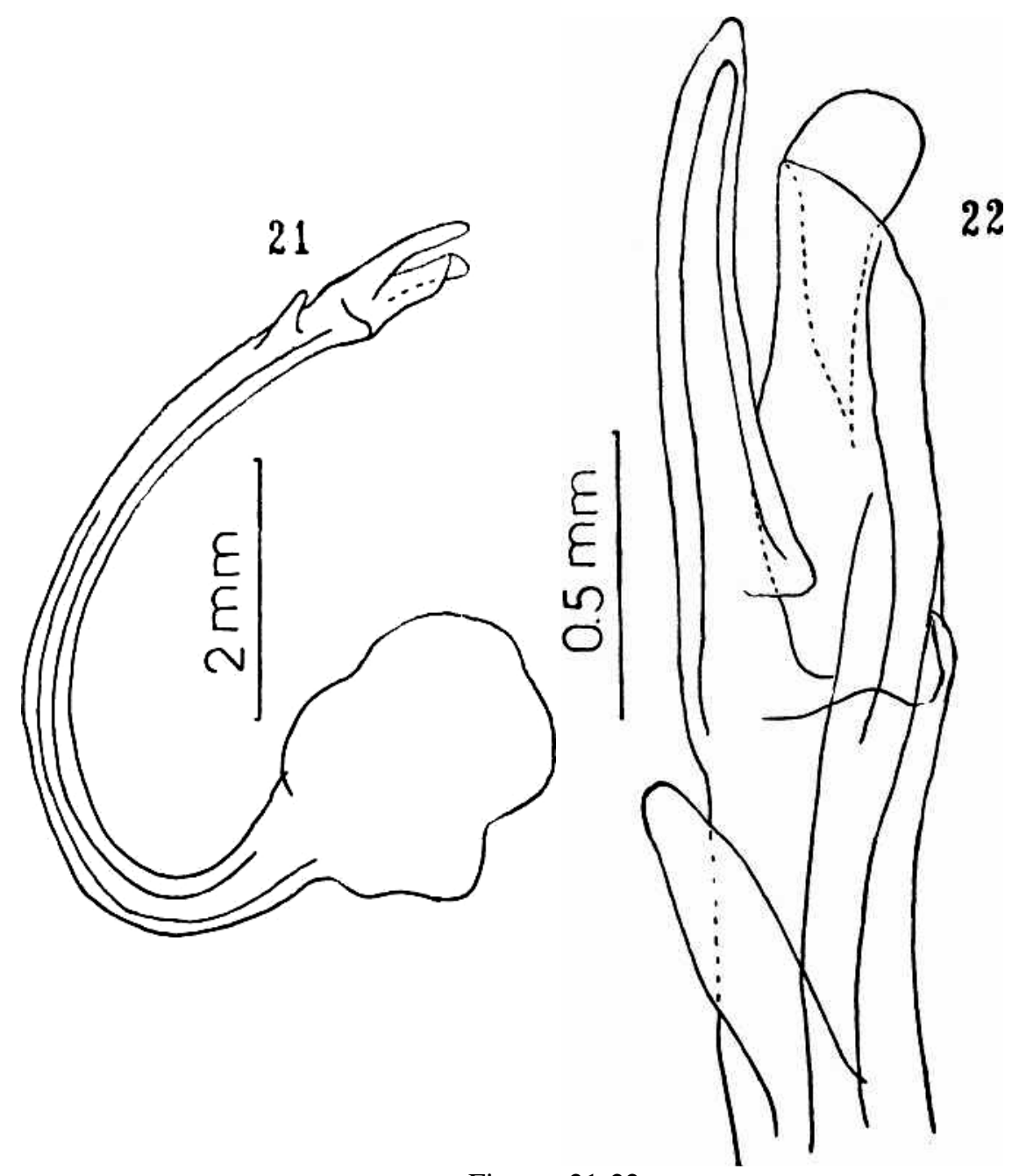

Figures 21-22.

First pleopod of $N$. (Neodorippe) japonica tahvanensis, male of 15.5 X 16: 21, entire pleopod. - 22, distal part. 

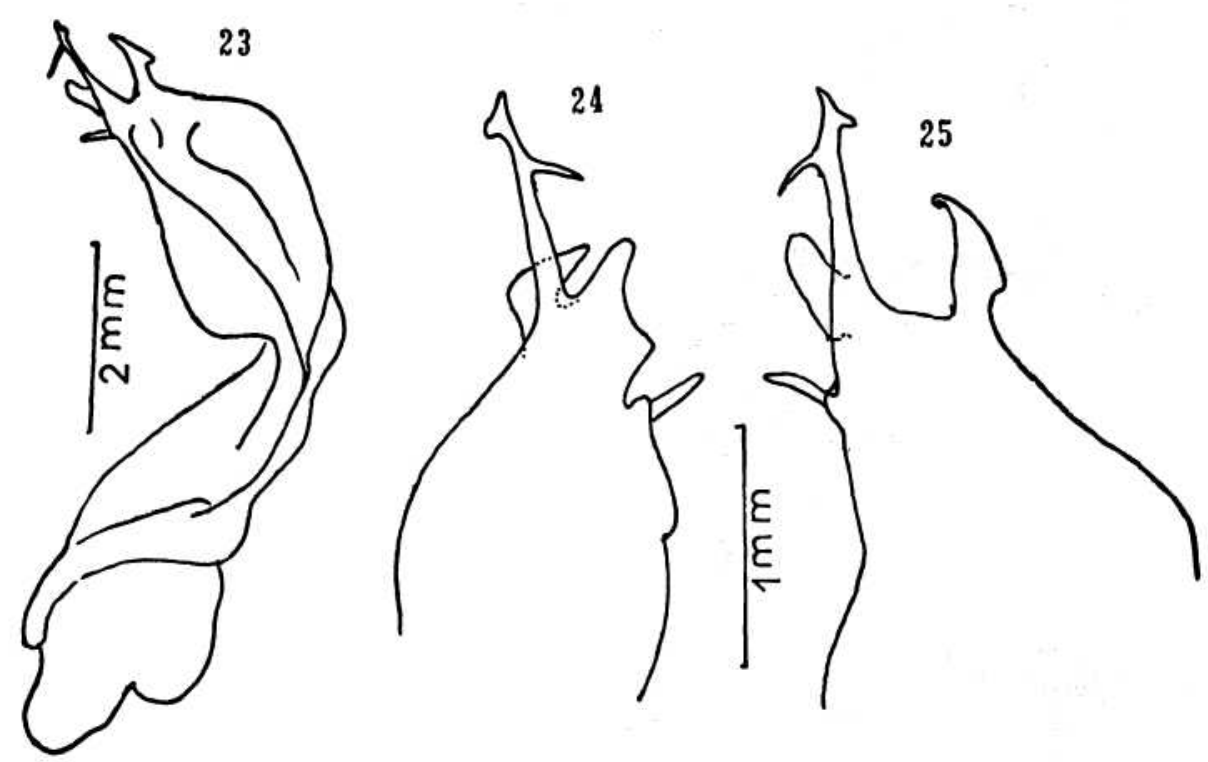

Figures 23-25.

First pleopod of Paradorippe granulata, male of 23 X 26: 23, entire pleopod. - 24-25 distal part, ventral and dorsal view. 


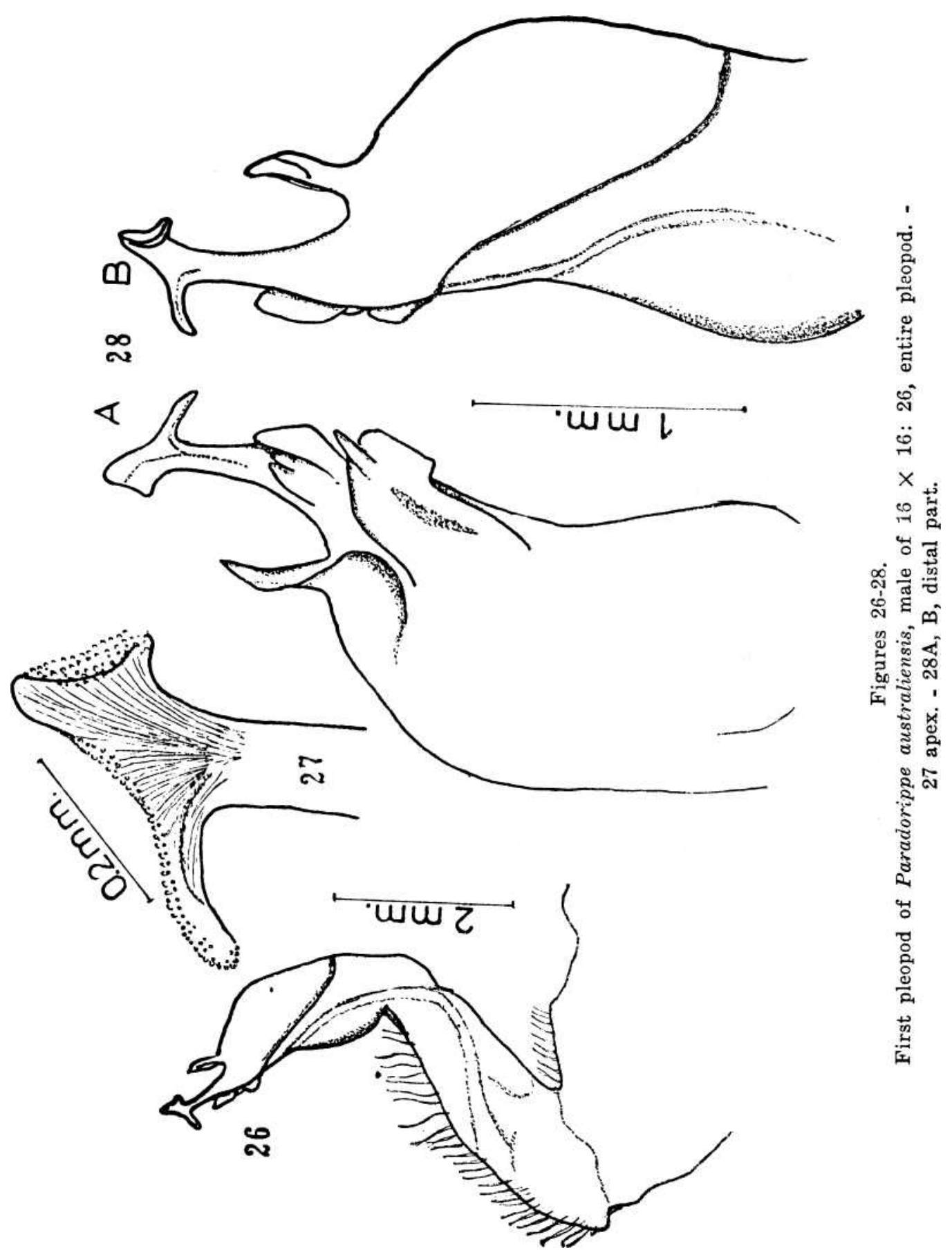




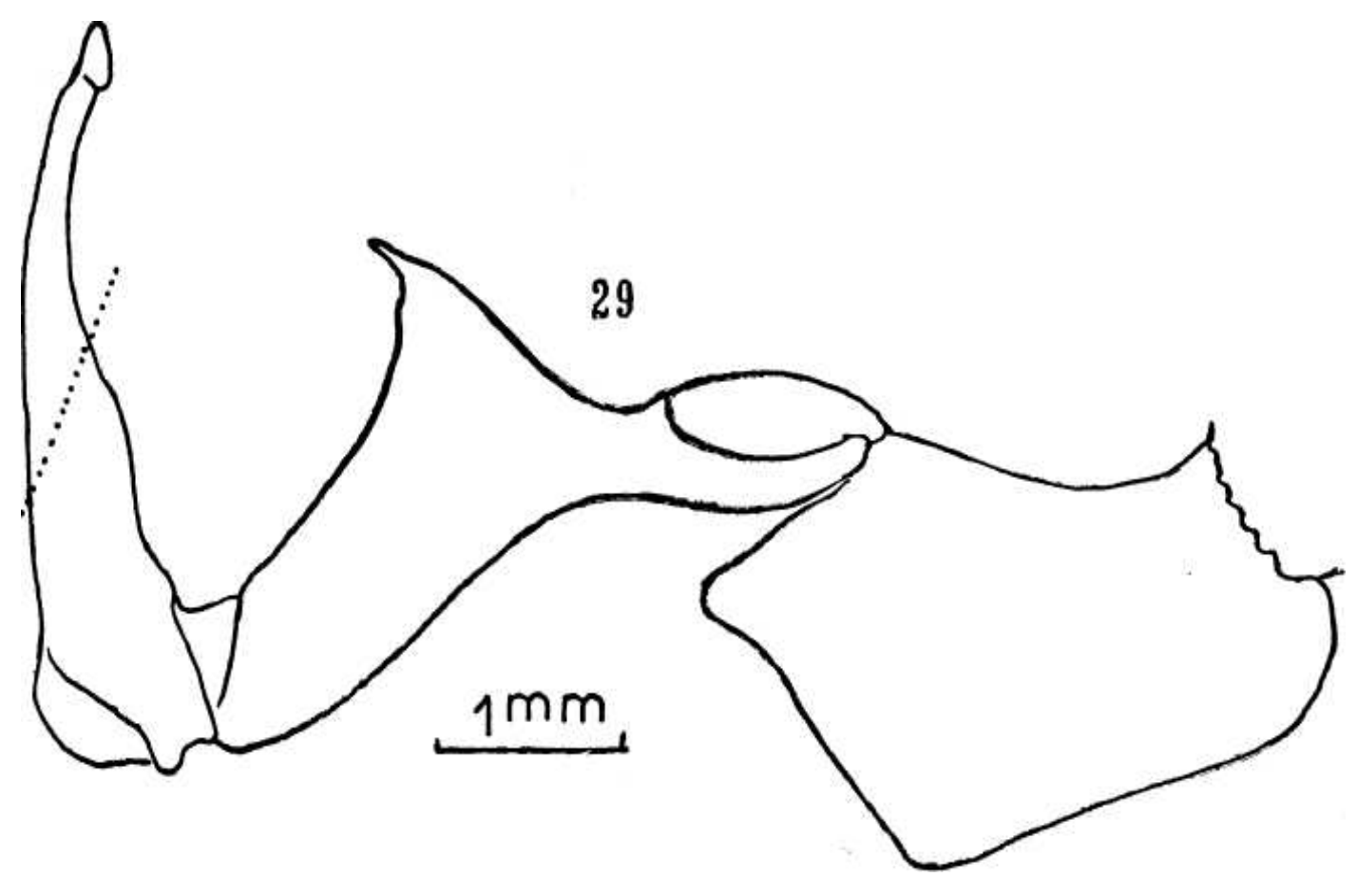

Figures 29.

Second pleopod of Paradorippe granulata, male of 23 X 26. 
Plate I.
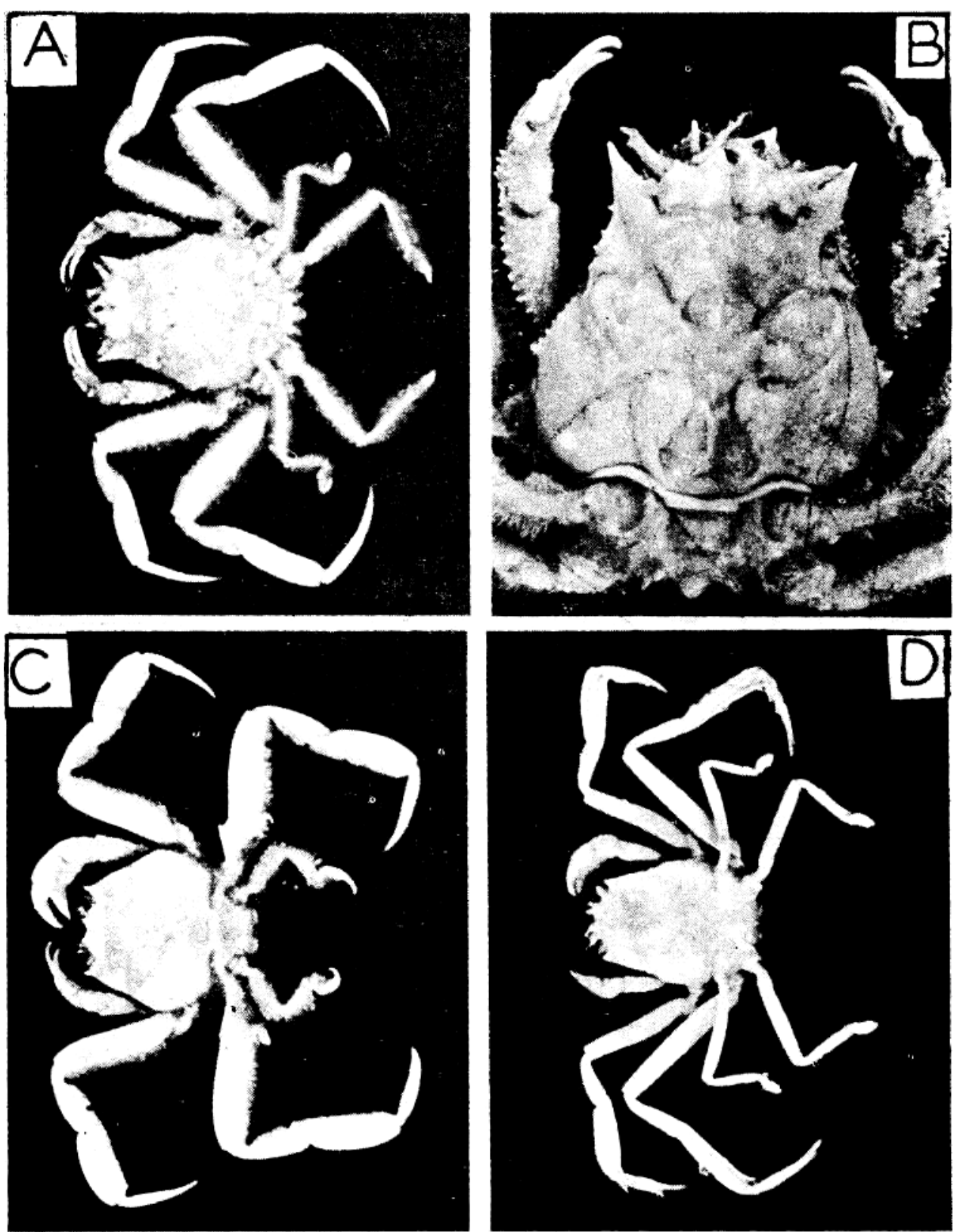

A - D. (Dorippe) frascone, male of $33 \times 33$, entire animal.

$\mathrm{B}$ - Same specimen, carapace.

C - D. (Dorippoides) facchino, male of 21 X 24, entire animal.

$\mathrm{D}-N$. (Neodorippe) astuta, male of $11 \mathrm{x} 10$, entire animal. 
Plate II.
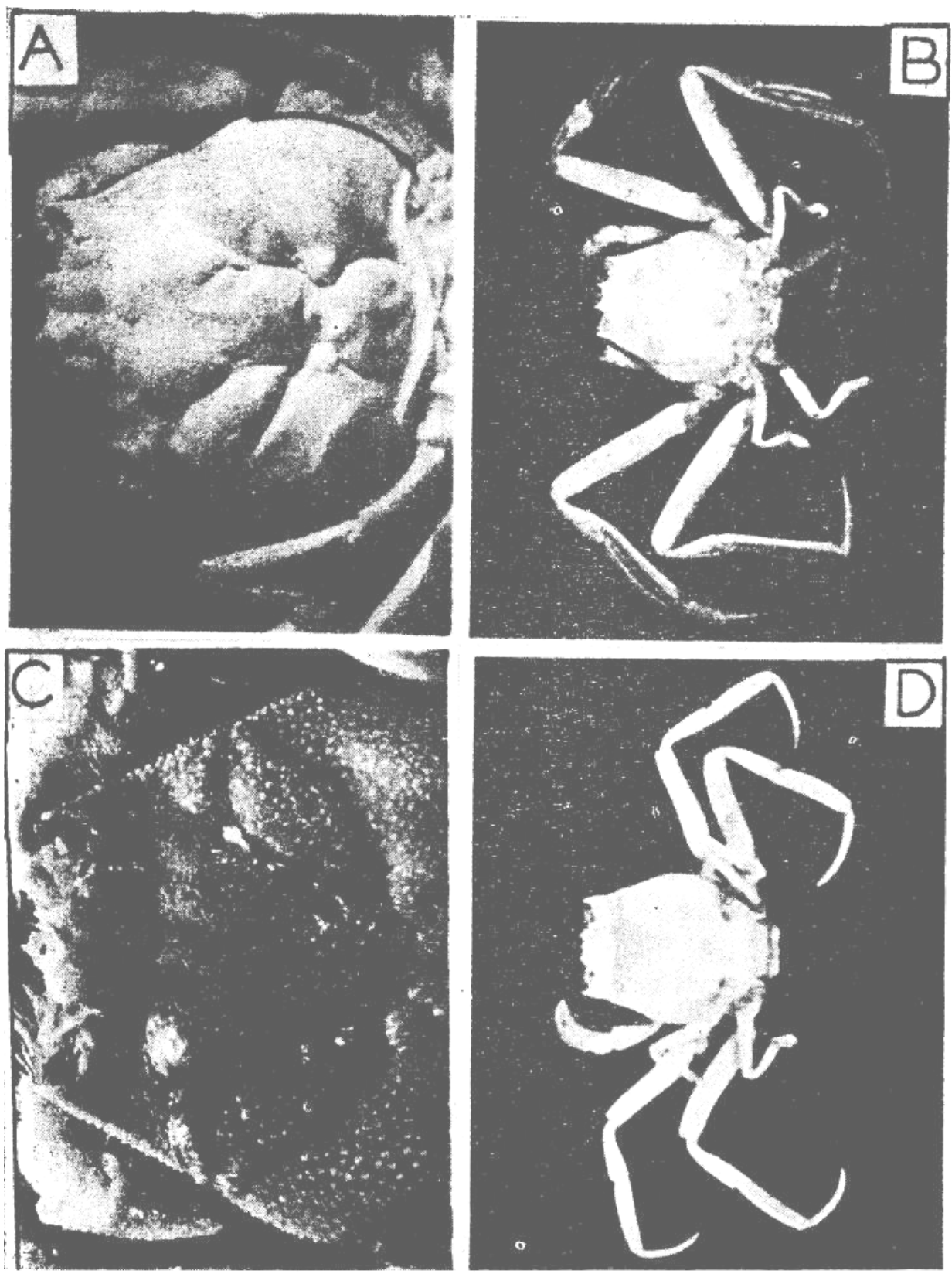

A $-N$. (Neodorippe) japonica, male of $17 \times 20$, carapace.

$\mathrm{B}-N$. (Nobilum) histrio, male of $21 \times 22$, entire animal.

C - Paradorippe granulata, male of $23 \times$ x 26, carapace.

$\mathrm{D}$ - Paradorippe australiensis, male of $16 \mathrm{x}$ 16, entire animal. 
Plate III.
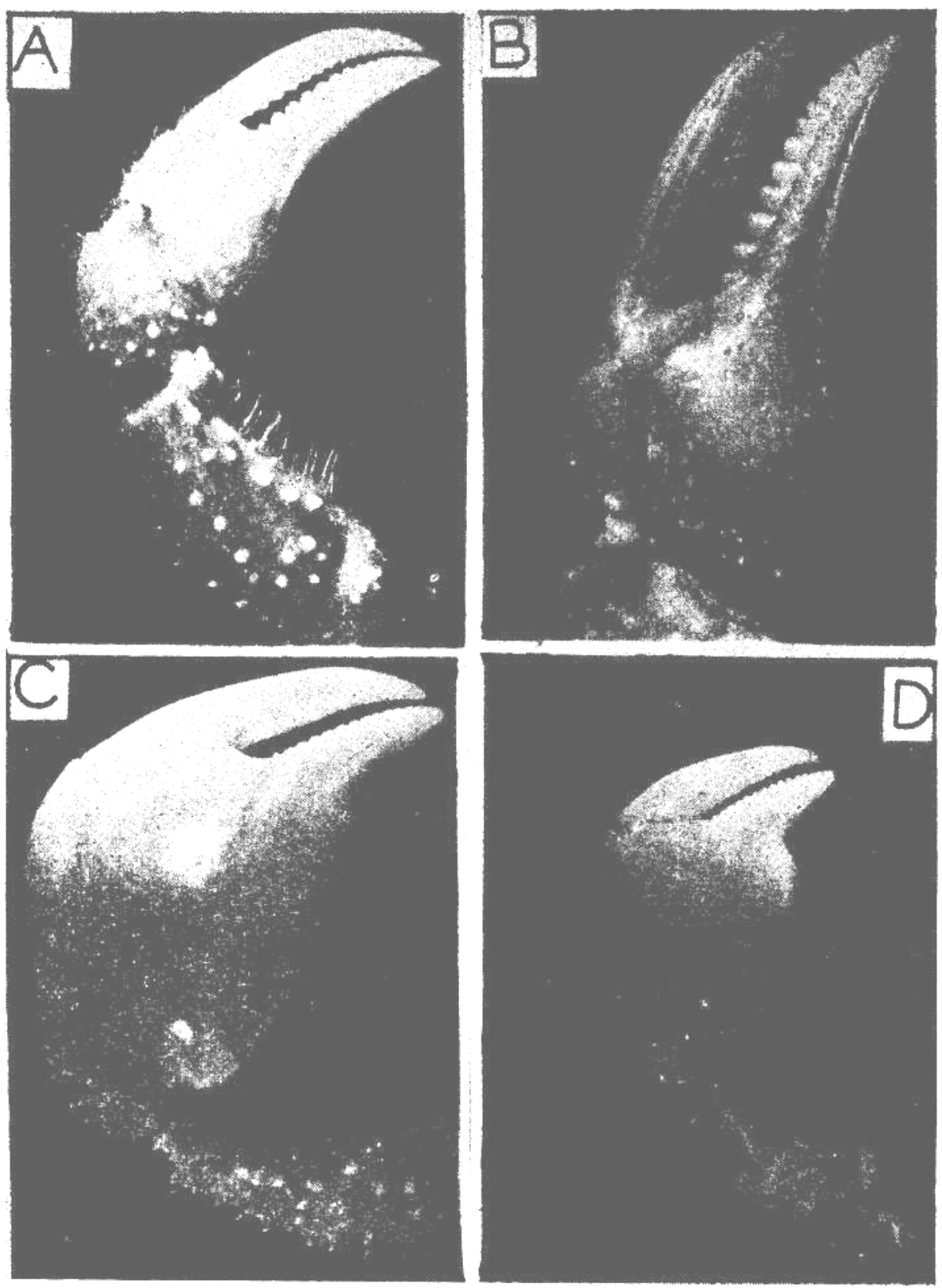

- Male chelipeds

A - D. (Dorippe) farscone, male of $33 \times 33$.

$\mathrm{B}$ - Same specimen, palm and fingers.

C - Same species but larger, male of $36 \times 36$.

D - D. (Dorippoides) facchino, male of $21 \times 24$. 


\section{Plate IV.}
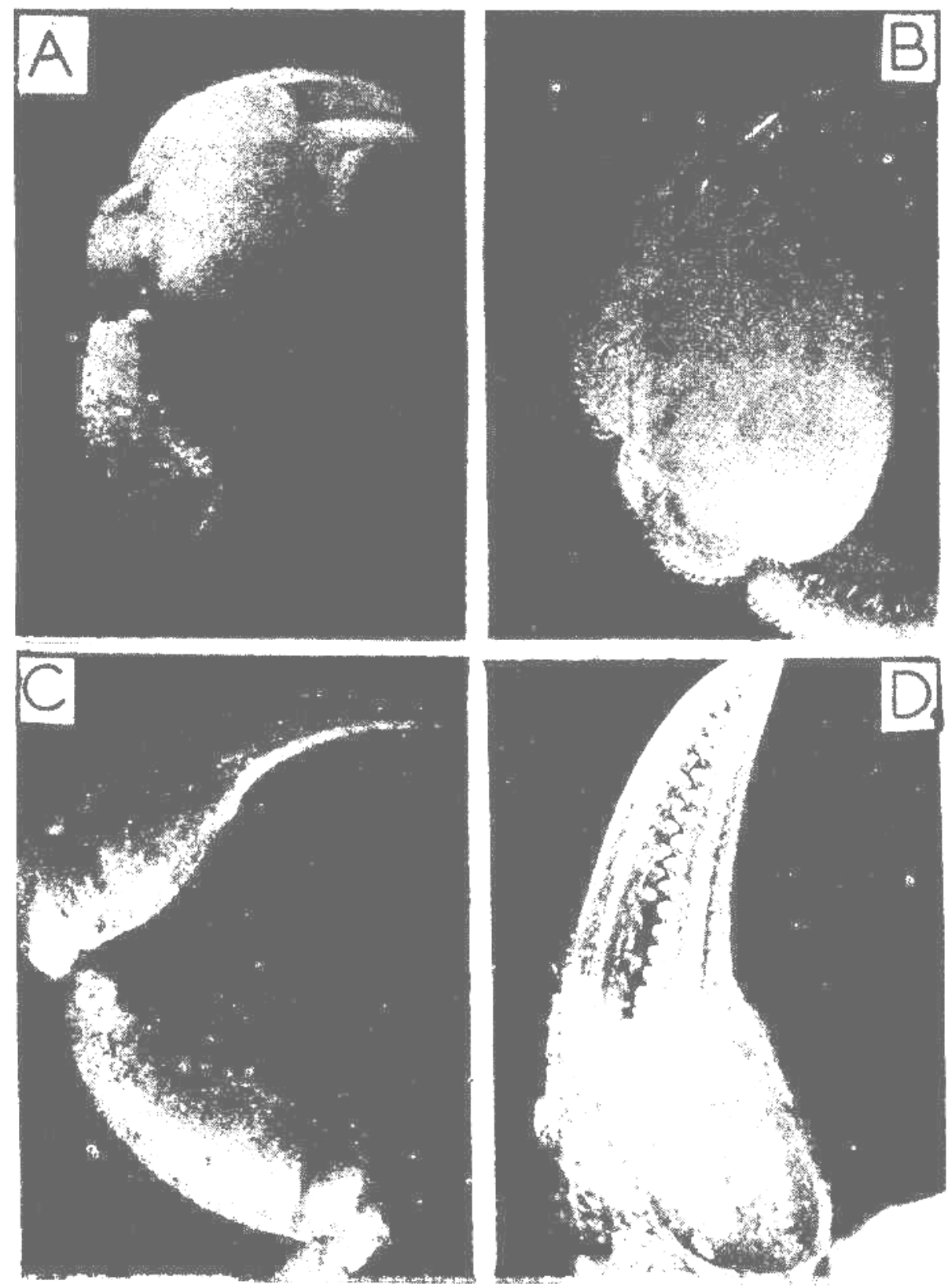

- Male chelipeds

A - N. (Neodorippe) astuta, male of 11 x 10 .

$\mathrm{B}$ - Same specimen, palm and fingers.

C - N. (Nobilum) histrio, male of 21 x 22

$\mathrm{D}$ - Same specimen, palm and fingers. 
Plate V.
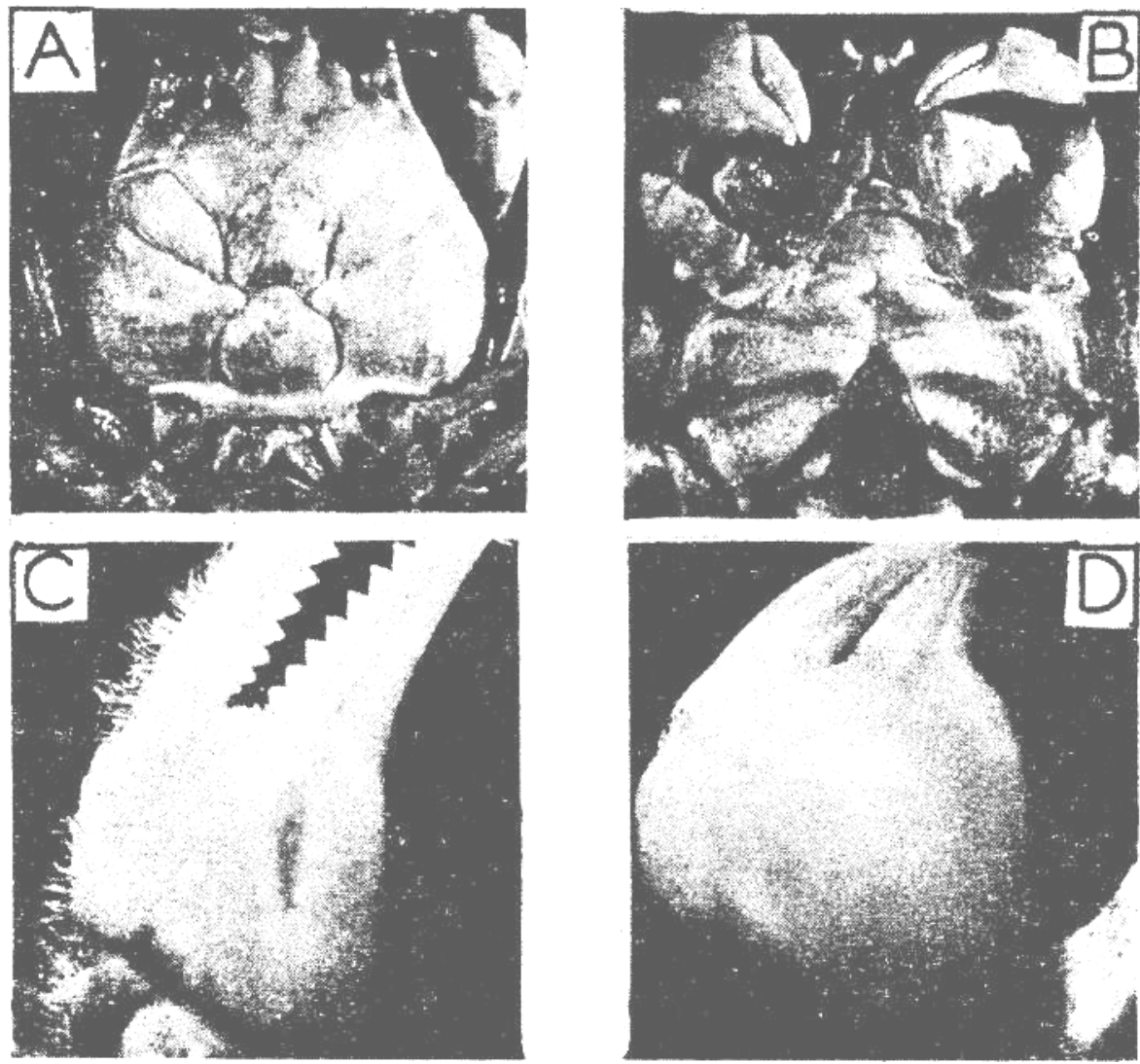

A - N (Neodorippe) "japonica taiwanensis, male of 15.5 x 16, carapace dorsal view. $\mathrm{B}$ - Same specimen, carapace ventral view.

C - TV. (Neodorippe) japonica, cheliped, male of 18 X 20.

D - TV. (Neodorippe) japonica taiwanensis, cheliped, male of 15.5 X 16 . 
Plate VI.
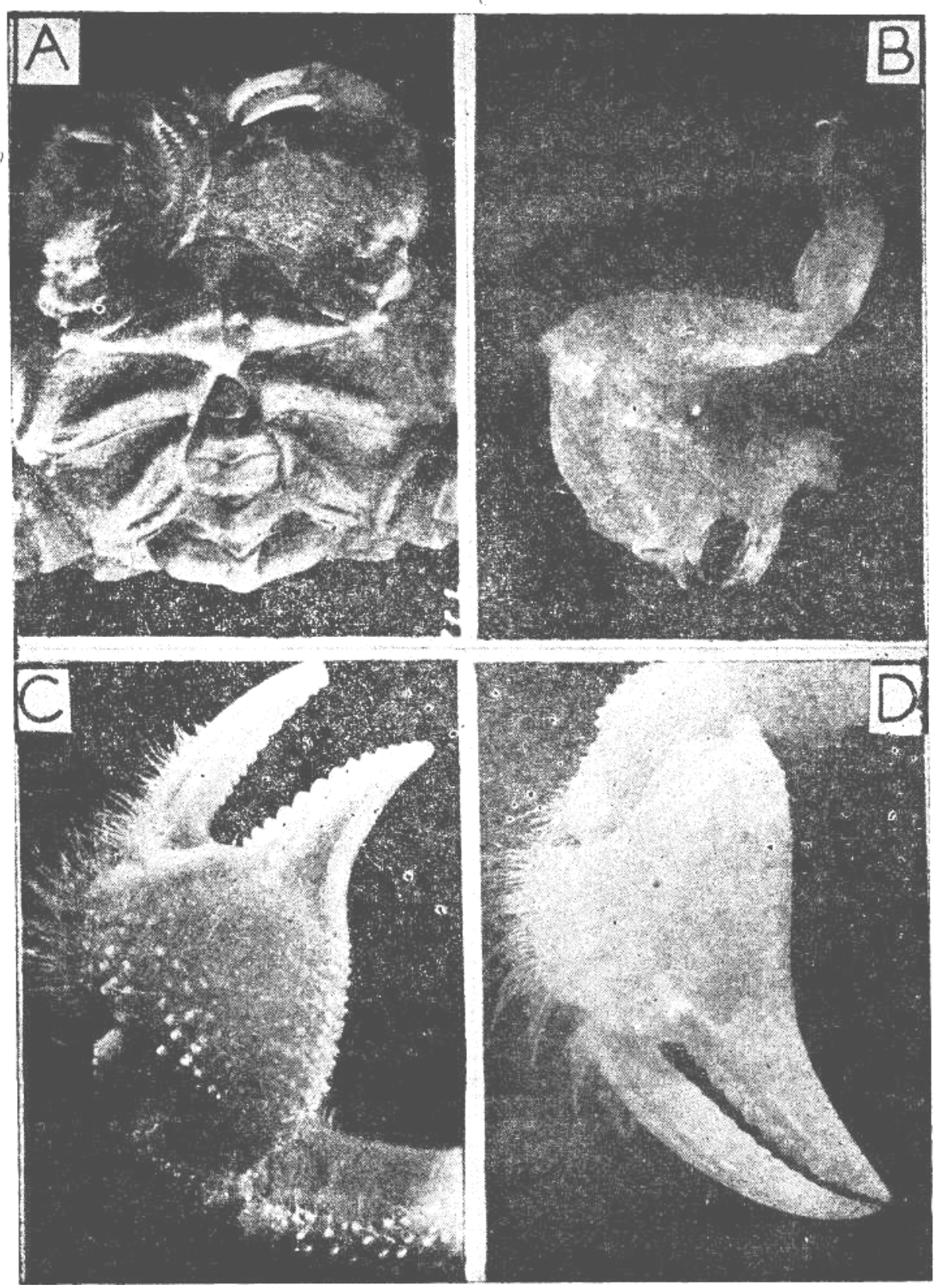

A $-N$. (Neodoyippe) japonica, male of $18 \times$ x 20, carapace ventral view.

$\mathrm{B}$ - Paradorippe australiensis, male of $16 \times 16$, pleopod 1, inner iew.

C - Paradorippe granulata, cheliped, male of 23 x 26.

$\mathrm{D}$ - Paradorippe australiensis, cheliped, male of $16 \times 16$. 